MARJORIE YUMI HASEGAWA

"Estudo comparativo entre as formas clínicas e relação com as variantes do vírus da Artrite-Encefalite Caprina isoladas no Estado de São Paulo"

São Paulo

2010 
MARJORIE YUMI HASEGAWA

\section{"Estudo comparativo entre as formas clínicas e relação com as variantes do vírus da Artrite-Encefalite Caprina isoladas no Estado de São Paulo"}

Dissertação apresentada do Programa de Pós-Graduação em Clínica Veterinária da Faculdade de Medicina Veterinária e Zootecnia da Universidade de São Paulo para obtenção do título de Mestre em Ciências

\section{Departamento:}

Clínica Médica

Área de concentração:

Clínica Veterinária

Orientadora: Prof. Dra. Lílian Gregory

São Paulo 
Autorizo a reprodução parcial ou total desta obra, para fins acadêmicos, desde que citada a fonte.

DADOS INTERNACIONAIS DE CATALOGAÇÃO-NA-PUBLICAÇÃO

(Biblioteca Virginie Buff D’Ápice da Faculdade de Medicina Veterinária e Zootecnia da Universidade de São Paulo)

Estudo comparativo entre as formas clínicas e relação com as variantes do vírus da Artrite-Encefalite Caprina isoladas no Estado de São Paulo / Marjorie Yumi Hasegawa. -- 2010.

77 p. : il.

Dissertação (Mestrado) - Universidade de São Paulo. Faculdade de Medicina Veterinária e Zootecnia. Departamento de Clínica Médica, São Paulo, 2010.

Programa de Pós-Graduação: Clínica Veterinária.

Área de concentração: Clínica Veterinária.

Orientador: Profa. Dra. Lilian Gregory.

1. Vírus. 2. Caprinos. 3. CAEV. 4. Ruminantes. I. Título. 
UNIVERSIDADE DE SÃO PAULO

FACULDADE DE MEDICINA VETERINÁRIA E ZOOTECNIA

Comissão de Ética no uso de animais

\section{CERTIFICADO}

Certificamos que o Projeto intitulado "Estudo comparativo entre as formas clínicas e as variantes do vírus da Artrite-encefalite caprina no Estado de São Paulo", protocolado sob o $\mathrm{n}^{\circ} 1326 / 08$, utilizando 100 (cem) caprinos, sob a responsabilidade da Profa. Dra. Lilian Gregory, está de acordo com os princípios éticos de experimentação animal da "Comissão de Ética no uso de animais" da Faculdade de Medicina Veterinária e Zootecnia da Universidade de São Paulo e foi aprovado "ad referendum".

We certify that the Research "Comparative study between the clinical manifestations and the distinct caprine arthritis-encephalitis virus types in São Paulo state", protocol number $1326 / 08$, utilizing 100 (hundred) caprine, under the responsibility Profa. Dra. Lilian Gregory, agree with Ethical Principles in Animal Research adopted by "Ethic Committee in the use of animals" of the School of Veterinary Medicine and Animal Science of University of São Paulo and was approved "ad referendum", meeting.

São Paulo, 11 de maio de 2010

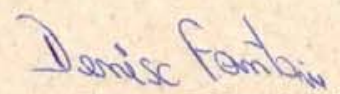

Profa. Dra. Denise Tabacchi Fantoni

Presidente

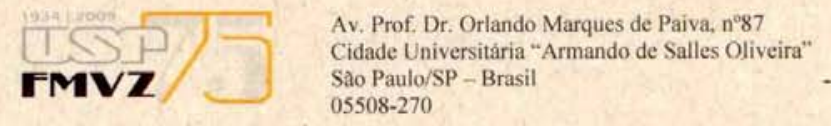
Fax: $+55113032-2224 / 3091-7757$ fone: $+55113091-7671 / 7676$ E-mail: fmvz@usp.br http://www.fmvz.usp.br


Nome: HASEGAWA, Marjorie Yumi

Título: Estudo comparativo entre as formas clínicas e relação com as variantes do vírus da Artrite-encefalite Caprina isoladas no estado de São Paulo

Dissertação apresentada do Programa de Pós-Graduação em Clínica Veterinária da Faculdade de Medicina Veterinária e Zootecnia da Universidade de São Paulo para obtenção do título de Mestre em Ciências

Data:

\section{Banca Examinadora}

Prof. Dr.: Instituição:

Julgamento:

Assinatura:

Prof. Dr.:

Instituição:

Julgamento:

Assinatura:

Prof. Dr.: Instituição:

Julgamento: Assinatura: 
Dedico esse trabalho à minha família com muito amor e gratidão

Ao meu pai Paulo À minha sempre querida Dalila Meus irmãos Paulo e Juliana Meu cunhado Marcelo E que seja um exemplo para meus queridos sobrinhos, João Paulo, Lucas e Nicole 


\section{AGRADECIMENTOS}

À minha orientadora Profa. Dra. Lilian Gregory pela amizade, confiança, incentivo, oportunidades de aprendizado e crescimento em minha profissão.

À Dra. Maria do Carmo Custódio S. H. Lara com quem iniciei meu primeiro trabalho durante a graduação, e pela amizade, confiança e incentivo, oportunidades de aprendizado e crescimento em minha profissão.

Aos Professores Dr. Fernando José Benesi, Dr. Wanderley Pereira de Araújo in memoriam, Dr. Eduardo Harry Birgel Júnior, Dr. Enrico Lippi Ortolani, Dra. Alice Della Libera, Dra. Maria Claudia Sucupira pelos ensinamentos em buiatria durante o período de graduação, residência, mestrado e as atividades do programa de aperfeiçoamento de ensino da disciplina de clínica médica.

Ao Prof .Dr. Edison Luiz Durigon, Dra. Maria Luisa Barbosa, Juliana Rodrigues Nogueira, Jansen Araújo, Lilian Walsh Keller, Raquel Negrão, Danielle Bruna do Laboratório de Virologia Clínica e Molecular do ICB-II/USP.

Ao Prof. Dr. Paulo Brandão pela paciência e colaboração.

Aos orientados da Profa. Dra. Lilian Gregory, Alessandra, Eduardo, Enoch, Huber e Laura, à Maria responsável pela limpeza do HOVET-Ruminantes pela profunda amizade e aos colegas do curso de pós graduação com quem convivi durante esse período.

Á Faculdade de Medicina Veterinária e Zootecnia da USP.

Ao CNPq pela concessão de auxílio financeiro da bolsa de mestrado. 


\section{RESUMO}

HASEGAWA, M. Y. Estudo comparativo entre as formas clínicas e relação com as variantes do vírus da Artrite-Encefalite Caprina isoladas no Estado de São Paulo. [Comparative study of the clinical forms and related variants of the virus isolated caprine arthritis encephalitis in the state of Sao Paulo]. 2010. $77 \mathrm{f}$. Dissertação (Mestrado em Ciências) - Faculdade de Medicina Veterinária e Zootecnia, Universidade de São Paulo, São Paulo, 2010.

Artrite-encefalite dos Caprinos (CAE) é uma enfermidade infecciosa, multissistêmica, causada por um lentivírus, e infecta caprinos de todas as idades, independente do sexo, raça e tipos de produção econômica. Os principais sintomas descritos são leucoencefalomielite, artrite, pneumonia crônica intersticial e mamite intersticial endurativa. A CAE possui distribuição mundial, no Estado de São Paulo encontra-se amplamente disseminada no rebanho caprino. Com o intuito de aprofundar os conhecimentos sobre o vírus da Artrite-encefalite dos caprinos (CAEV) serão realizados estudos de sequenciamento de parte do cDNA e análise filogenética de amostras detectadas de órgãos, líquido sinovial, sêmen e leite de caprinos naturalmente infectados e soropositivos ao IDGA para o vírus da CAE e correlacionar as variantes genéticas com a sintomatologia, a forma clinica preferencial e a patogenicidade. Para o estudo filogenético serão amplificados, por RT-PCR, e sequenciados, parte do gene pol e o gene tat das amostras. Este estudo possibilitará o conhecimento das estirpes virais existentes no rebanho caprino do estado de São Paulo e a sua patogenicidade. A pesquisa de mutações encontradas por meio da análise do estudo filogenético do vírus poderá mostrar se a variante encontrada apresenta predileção por uma determinada expressão clínica. O seqüenciamento genético poderá permitir, também no futuro, uma maior eficiência na produção de antígenos virais para sorodiagnóstico e vacinas a partir das cepas circulantes encontradas.

Palavras-chave: Vírus, Caprino, CAEV, Clínica, Ruminantes. 


\begin{abstract}
HASEGAWA, M. Y. Comparative study of the clinical forms and related variants of the virus isolated caprine arthritis encephalitis in the state of Sao Paulo. [Estudo comparativo entre as formas clínicas e relação com as variantes do vírus da Artrite-Encefalite Caprina isoladas no Estado de São Paulo]. 2010.77 f. Dissertação (Mestrado em Ciências) - Faculdade de Medicina Veterinária e Zootecnia, Universidade de São Paulo, São Paulo, 2010.

Caprine arthritis-encephalitis (CAE) is an infectious disease, multisystem caused by a lentivirus, and infects goats of all ages, regardless of sex, race and types of economic production. The main symptoms are leukoencephalomyelitis, arthritis, chronic interstitial pneumonia and interstitial mastitis induration. CAE has a worldwide distribution in the State of São Paulo is widely disseminated in the goat herd. Aiming to deepen knowledge about the virus caprine arthritis-encephalitis (CAEV) studies will be performed sequencing of part of the cDNA and phylogenetic analysis of samples detected in organs, synovial fluid, semen and milk of goats naturally infected and seropositive AGID test for CAE virus and to correlate genetic variants with the symptoms, the clinical form of preferential and pathogenicity. For the phylogenetic study will be amplified by RT-PCR and sequenced, part of the pol gene and the gene tat of the samples. This study will allow the knowledge of existing viral strains in goat herd in the state of Sao Paulo and its pathogenicity. The analysis of mutations found by analyzing the phylogenetic analysis of the virus may show if the variant has found a predilection for a particular clinical expression. The gene sequencing will allow, in future, greater efficiency in the production of viral antigens for serodiagnosis and vaccines from the circulating strains found.
\end{abstract}

Keywords: virus, caprine, CAEV, clinics, ruminants. 


\section{LISTA DE FIGURAS}

FIGURA 1 - ESQUEMA DOS COMPONENTES DA PARTÍCULA VIRAL DO CAEV ....................19

FIGURA 2 - ESTRUTURA DOS PROVÍRUS DOS LENTIVÍRUS CAEV .............................20

FIGURA - 3 ESQUEMA DA REPLICAÇÃO E PRODUÇÃO DA PARTÍCULA VIRAL .......................21

FIgURA 4 - CARPOS AUMENTADOS DE VOLUME EM ANIMAL CAE POSITIVO. ......................30

FIGURA 5 - ARTICULAÇÃO ATLANTO-OCCIPITAL EM ANIMAL CAE POSITIVO. .......................31

FIGURA 6 - ANIMAL CAE POSITIVO MOSTRANDO APOIO EM CARPOS .............................32

FIGURA 7 - RADIOGRAFIA DE CARPO EM ANIMAL CAE POSITIVO COM ARTRITE À ESQUERDA E OUTRO NORMAL À $\quad$ DIREITA. ...................................................... 32

FIGURA 8 - ANIMAIS CAE + APRESENTANDO PARESIA DOS MEMBROS POSTERIORES UNI OU BILATERAL.

FIGURA 9 - EVIDENCIAÇÃO DO VÍRUS EM MICROSCOPIA ELETRÔNICA .............................36

FIGURA 10 - DETERMINAÇÃO INDIRETA POR IMUNODIFUSÃO EM GEL DE AGAR (IDGA).......36

FIGURA 11 - DETERMINAÇÃO INDIRETA POR ENSAIO IMUNOENZIMÁTICO (ELISA) ..............37

FIGURA 12 - DETECÇÃO DA PRESENÇA DE ANTICORPOS POR IMUNOFLUORESCÊNCIA INDIRETA (IFI)

FiguRA 13 - ELETROFORESE EM GEL DE AGAROSE APÓS REAÇÃO DE PCR DO DNA PROVIRAL DO CAEV

FIGURA 14 - A FIGURA MOSTRA A OCORRÊNCIA DE CAEV EM DIFERENTES TIPOS DE LIQUIDO CORPORAIS COLETADOS DOS CAPRINOS .55

FIGURA 15 - ÁRVORE FILOGENÉTICA DOS SEQÜENCIADOS DE CAEV NO BRASIL E NO MUNDO 


\section{LISTA DE TABELAS}

TABela 1 - TABela demonstrativa da PREVALÊNCIA dA CAE EM ALgUnS PAíses.

TABELA 2 - DISTRIBUIÇÃO DAS TAXAS DE PREVALÊNCIA DA INFECÇÃO PELO CAEV DOS CAPRINOS NO BRASIL, UTILIZANDO A PROVA DE IMUNODIFUSÃO EM GEL DE ÁGAR, SEGUNDO O ANO DE AVALIAÇÃO, AUTOR DA PESQUISA E O ESTADO DA OCORRÊNCIA.

TABELA 3 - INFLUÊNCIA DO SEXO NA PREVALÊNCIA DA CAE.

TABELA 4 - INFLUÊNCIA DA RAÇA NA PREVALÊNCIA DA CAE. 25

TABELA 5 - INFLUÊNCIA DO SISTEMA DE CRIAÇÃO NA PREVALÊNCIA DA CAE. 25

TABELA 6 - INFLUÊNCIA DA IDADE EM MESES NA FREQÜÊNCIA DE SOROPOSITIVOS EM CAPRINOS.

TABELA 7 - OLIGONUCLEOTÍDEOS INICIADORES USADOS NA PCR PARA AMPLIFICAÇÃO DO GENE POL

TABELA 8 - RELAÇÃO DE TODOS OS ISOLADOS SEQÜENCIADOS, TIPO DE AMOSTRA CLÍNICA E ANIMAIS

TABELA 9 - NIVEL DE IDENTIDADE DO GRUPO INTERNO MARJORIE (IDS B1 MARJORIE), ONDE COMPARA-SE O SEQÜENCIADO POR MARJORIE COM O DELA MESMA; IDENTIDADE DO GRUPO SEQÜENCIADO B DO GEN BANK (IDS B-GB); IDENTIDADE DO GRUPO B BRASILEIRO DO GEN BANK (IDS B-BR-GB); IDENTIDADE DO GRUPO SEQÜENCIADO POR MARJORIE VERSUS O GRUPO B DO GEN BANK (IDS B1 MARJORIE VS. B-GB); IDENTIDADE DO GRUPO SEQÜENCIADO POR MARJORIE VERSUS O GRUPO B BRASILEIRO DO GEN BANK (IDS B1 MARJORIE VS. B-BR$\mathrm{GB})$ 


\section{LISTA DE ABREVIATURAS E SIGLAS}

\begin{tabular}{|c|c|c|}
\hline CAEV & - & vírus da Artrite e Encefalite Caprina \\
\hline OIE & - & Organização internacional de epizootias \\
\hline FAO & - & Food Agricultural organization \\
\hline PCR & - & Polimerase chain reaction \\
\hline DNA & - & ácido desoxibonucleico \\
\hline RNA & - & ácido ribonucléico \\
\hline CAE & - & Artrite encefalite caprina \\
\hline Gag & - & Group Antigen \\
\hline pol & - & polimerase \\
\hline env & - & envelope \\
\hline IBGE & - & Instituto Brasileiro de Geografia e Estatística \\
\hline AEC & - & Caprine Arthritis and encephalitis \\
\hline EIA & - & anemia infecciosa eqüina \\
\hline FIV & - & vírus da imunodeficiência felina \\
\hline BIV & - & vírus da imunodeficiência bovina \\
\hline SIV & - & vírus da imunodeficiência símia \\
\hline HIV & - & vírus da imunodeficiência humana \\
\hline PNSCO & - & Programa Nacional de Sanidade Caprinos e Ovinos \\
\hline MAPA & - & Ministério da Agricultura e Pecuária \\
\hline IDGA & - & Imunodifusão em agar gel \\
\hline MV & - & Vírus Maedi-Visna \\
\hline ELISA & - & Enzyme Linked Immuno Sorbent Assay \\
\hline IFI & - & Imunofluorescência indireta \\
\hline LVPR & - & Lentiviroses de Pequenos Ruminantes \\
\hline
\end{tabular}




$\begin{array}{lll}\mu \mathrm{L} & - & \text { microlitro } \\ \mathrm{mM} & - & \text { milimol } \\ \mathrm{TBE} & - & \text { Tris Borato } \\ \mathrm{EDTA} & - & \text { ácido etilenodiamino tetra-acético } \\ \mu \mathrm{g} / \mathrm{mL} & - & \text { micrograma/mililitro } \\ \mathrm{MgCl} 2 & - & \text { Cloreto de magnésio } \\ \mathrm{KCl} & - & \text { Cloreto de potássio } \\ \mathrm{rpm} & - & \text { rotações por minuto } \\ \mathrm{A} & - & \text { adenina } \\ \mathrm{G} & - & \text { guanina } \\ \mathrm{T} & - & \text { timina } \\ \mathrm{C} & - & \text { citosina }\end{array}$




\section{LISTA DE SÍMBOLOS}

${ }^{\circ} \mathrm{C} \quad-\quad$ graus Celsius

$\circledR \quad$ - $\quad$ marca registrada 


\section{SUMÁRIO}

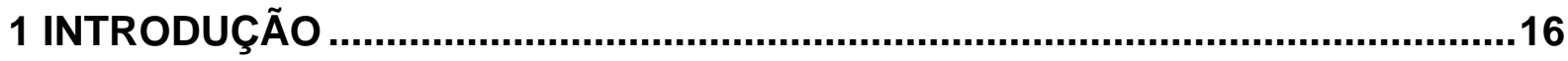

2 OBJETIVOS............................................................................................. 18

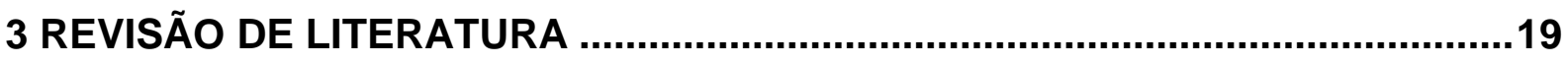

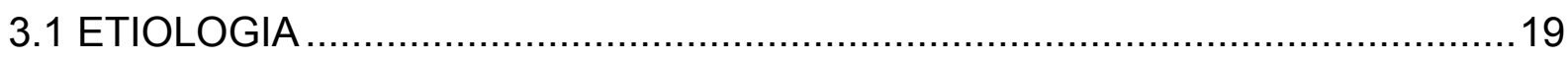

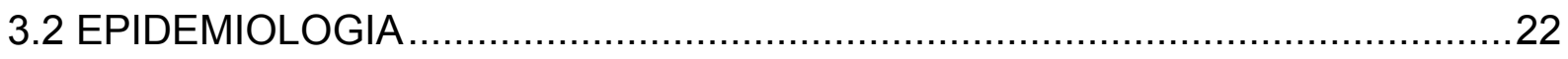

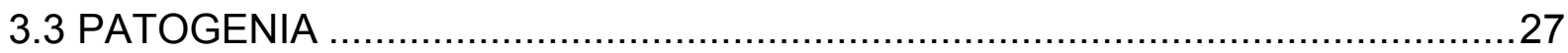

3.4 ASPECTOS CLÍNICOS E ANATOMO-HISTOPATOLÓGICOS ........................29

3.4.1 Forma Clínica Articular ..........................................................................29

3.4.2 Forma Clínica Mamária ........................................................................... 32

3.4.3 Forma Clínica Pulmonar ........................................................................ 33

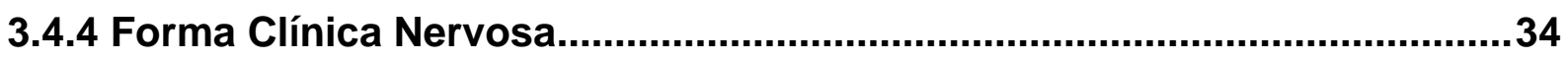

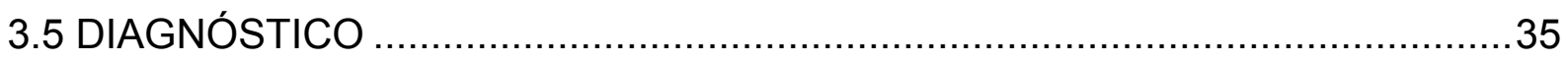

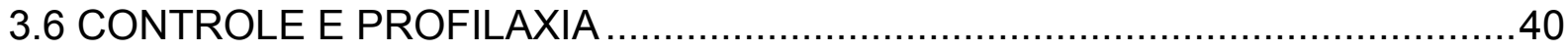

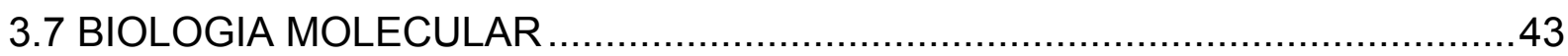

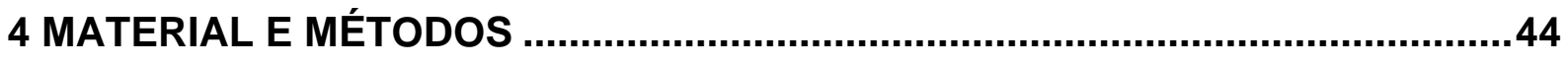

4 MATERIAL E MÉTODOS .............................................................................45

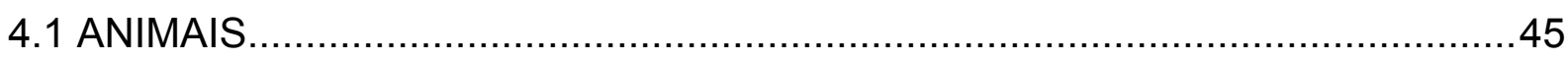

4.2 COLHEITA E PROCESSAMENTO DAS AMOSTRAS DE SANGUE .................45

4.3 PROVA DE SORODIAGNÓSTICO PARA O VÍRUS DA ARTRITE-ENCEFALITE

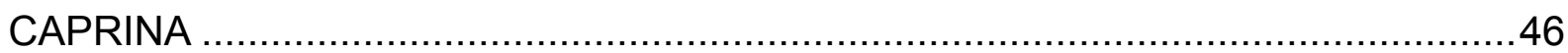

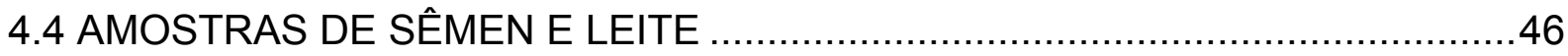

4.5 EXTRAÇÃO DAS AMOSTRAS CLÍNICAS ............................................4

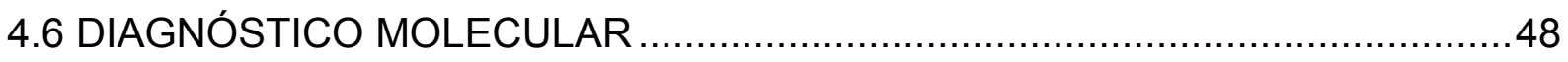

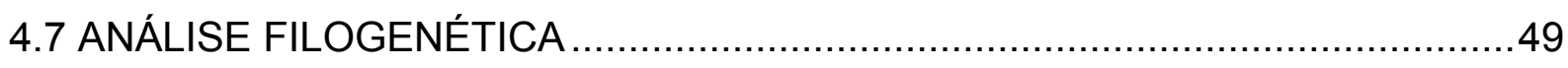

4.7.1 Purificação do produto amplificado ......................................................49

4.7.2 Reação de seqüenciamento ....................................................................50

4.7.3 Precipitação da Reação de seqüenciamento..............................................51

4.8 ANÁLISE E ALINHAMENTO DAS SEQÜÊNCIAS .................................. 51

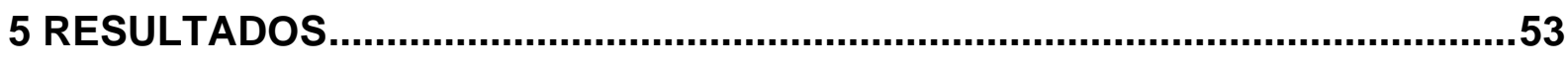

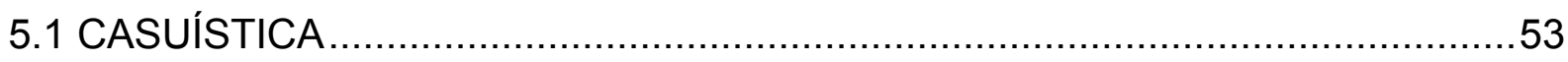

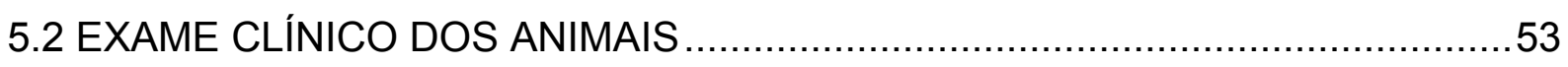

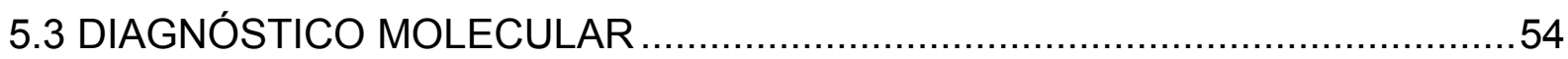




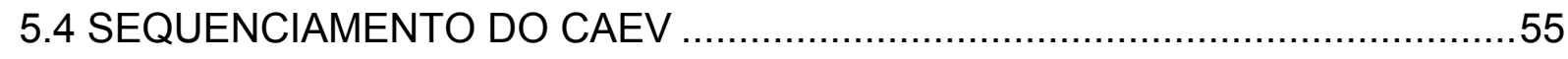

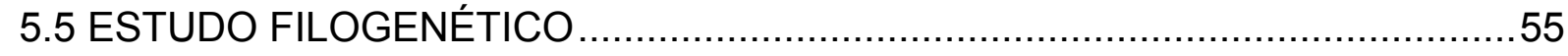

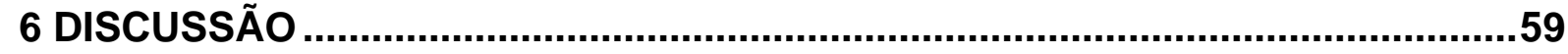

7 CONCLUSÕES ..........................................................................................60

REFERÊNCIAS............................................................................................... 61

ANEXOS .................................................ERRO! INDICADOR NÃO DEFINIDO. 


\section{INTRODUÇÃO}

O Brasil possui um rebanho caprino bastante significativo no contexto pecuário mundial: 10.306 .722 cabeças. Na região Nordeste concentra-se o maior número desses animais, representando, aproximadamente $92 \%$ do plantel nacional. A estimativa do rebanho de caprinos, nas várias regiões geo-econômicas do Brasil, segundo o IBGE - Pesquisa Pecuária Municipal em 2005 é a seguinte: Região Norte - 154.678 cabeças; Região Nordeste - 9.542 .910 caprinos; Região Sudeste 252.124 animais; Região Centro-Oeste - 114.297 caprinos e Região Sul - 242.713 cabeças.

Mesmo se tratando de um sistema de criação muito antigo em nosso país, a caprinocultura ainda apresenta uma série de problemas, que dificultam a produção econômica desses animais e necessitam de urgentes soluções, visando minorar os grandes prejuízos que causam a essa produção agropastoril. De fundamental importância dentre esses fatores, destacam-se as enfermidades infecto-contagiosas ainda muito comuns nos rebanhos brasileiros, associadas a outras, ainda consideradas como emergentes. Entre elas poderiam ser destacadas as verminoses, as broncopneumonias, as doenças dos recém-nascidos, a linfadenite caseosa e a micoplasmose. Além dessas enfermidades, atualmente, merece destaque a ArtriteEncefalite dos Caprinos (AEC, também reconhecida como CAE - abreviação do inglês $\underline{\text { Caprine }}$ Arthritis-Enncephalitis).

O primeiro relato de lesões sugestivas da infecção pelo vírus da $\mathrm{CAE}$ causando poliartrite crônica foi descrito na Suíça por Stünzi et al.(1964). Posteriormente foram descritos poliartrite crônica, no Japão (NAKAGAWA et al., 1971), poliartrite e lesões granulomatosas com desmielinização cerebral, na Alemanha (STAVROU et al., 1969) e leucoencefalomielite, nos Estados Unidos (CORK et al., 1974).

O vírus da CAE foi isolado pela primeira vez nos Estados Unidos da América (EUA), em 1979, da membrana sinovial e do líquido cefalorraquidiano de caprinos infectados. O reconhecimento internacional da CAE como uma virose ocorreu em 1980, após a identificação do agente, classificado como um lentivirus da família Retroviridae (CRAWFORD et al., 1980). 
A Artrite-Encefalite Caprina é uma doença exótica, introduzida no Brasil pela inadequada importação de reprodutores de países, que convivem de forma perigosa com a doença. Sua disseminação em nosso país deu-se através da indiscriminada distribuição de matrizes impulsionada pelo crescimento da caprinocultura leiteira, com excelente padrão genético de raças especializadas, porém infectadas, oriundas de regiões de tradicional criação de caprinos onde a doença é endêmica como França, Suíça, Holanda, Alemanha, Inglaterra, Canadá e Estados Unidos. O primeiro relato de animais soropositivos e o isolamento do vírus da CAE foram feitos no Rio Grande do Sul (MOOJEN et al., 1986; HÖTZEL et al., 1993), porém há registros de exames positivos em soros coletados, no Rio de Janeiro, no início da década de 80 (CUNHA; NASCIMENTO, 1995).

A CAE foi definida como uma enfermidade infecciosa, multissistêmica, causada por vírus pertencente ao gênero Lentivirus e família Retroviridae. A este mesmo gênero pertencem outros vírus de importância em patologia veterinária e humana, como os vírus da anemia infecciosa eqüina (EIA), da Pneumonia Progressiva Ovina (Maedi-Visna) e das imunodeficiências felina (FIV), bovina (BIV), símia (SIV) e humana (HIV) (LEGASTELOIS et al., 1996b).

$\mathrm{O}$ vírus da CAE infecta caprinos de todas as idades, independente do sexo, raça e tipos de produção econômica. Os principais sintomas descritos em casos clínicos desta doença caracterizaram duas formas clínicas preponderantes: a leucoencefalomielite, que acomete cabritos (CORK et al., 1974) e a artrite, mais freqüente nos animais adultos (CRAWFORD et al., 1980). Além dessas manifestações clínicas bem definidas, o pulmão e a glândula mamária dos caprinos foram considerados como passíveis de comprometimento nas infecções causadas pelo mencionado vírus, determinando outras duas formas clínicas bem definidas, respectivamente: a pneumonia crônica intersticial, freqüentemente denominada por pneumonia progressiva dos caprinos (SIMS et al., 1983); e outra mamária - a mamite intersticial endurativa (WOODARD et al., 1982; LERONDELLE et al., 1989; ROSADIO et al., 1993; SMITH e SHERMAN, 1994; SERAKIDES et al., 1996). 


\section{OBJETIVOS}

O objetivo deste estudo é relacionar as formas clínicas da artrite encefalite caprina com as variantes do vírus dos isoladas dos caprinos criados no Estado de São Paulo. Sabe-se da inexistência de conhecimentos das variantes virais circulantes no estado de São Paulo. Para a elucidação dos questionamentos levantados faz-se necessária a amplificação e a caracterização molecular das sequencias virais existentes no estado. 


\section{REVISÃO DE LITERATURA}

\subsection{ETIOLOGIA}

O agente etiológico causador da artrite encefalite dos caprinos é classificado como pertencente à família Retroviridae, do gênero Lentivirus, promovendo o aparecimento de doenças de incubação e evolução lentas em várias espécies de animais domésticos com lesões degenerativas e/ou inflamatórias de vários tecidos (CRAWFORD et al., 1980; FRANCKI et al., 1991; CASTRO, 1998). Os lentivírus geralmente são não oncogênicos, porém espécie-específicos e apresentam alta taxa de mutação, com conseqüente diversidade genotípica e fenotípica (CASTRO, 1998).

A partícula viral é composta pelos produtos do gene gag ("Group Antigen"), pol (polimerase), env (envelope) e pelo RNA genômico (Figura 1). Os genes gag e pol são os mais conservados, enquanto que o gene env é altamente heterogêneo. $O$ genoma viral também é constituído pelos genes vif (infectividade do virion) e tat (ativador da transcrição) (Figura 2).

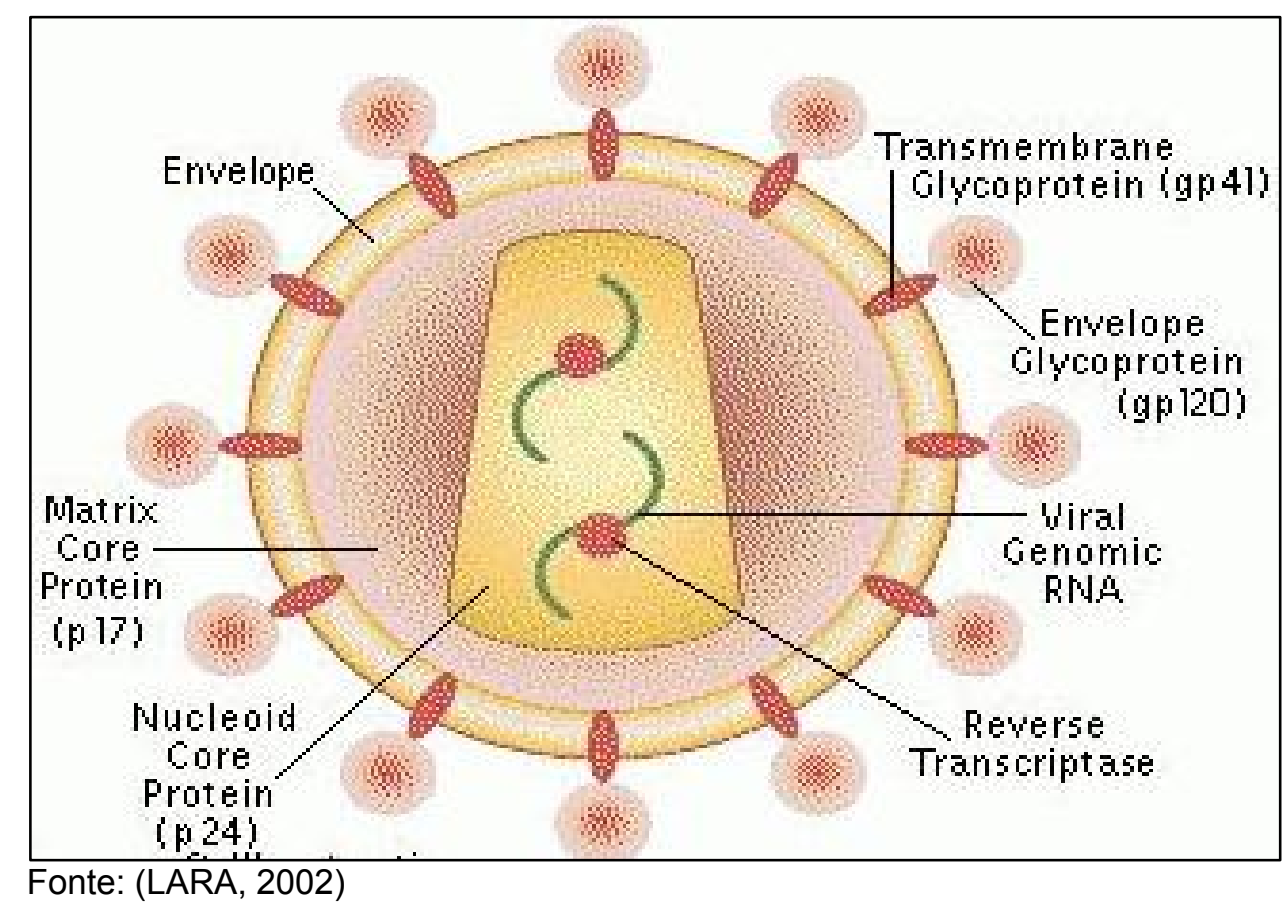

Figura 1 - Esquema dos componentes da partícula viral do CAEV 


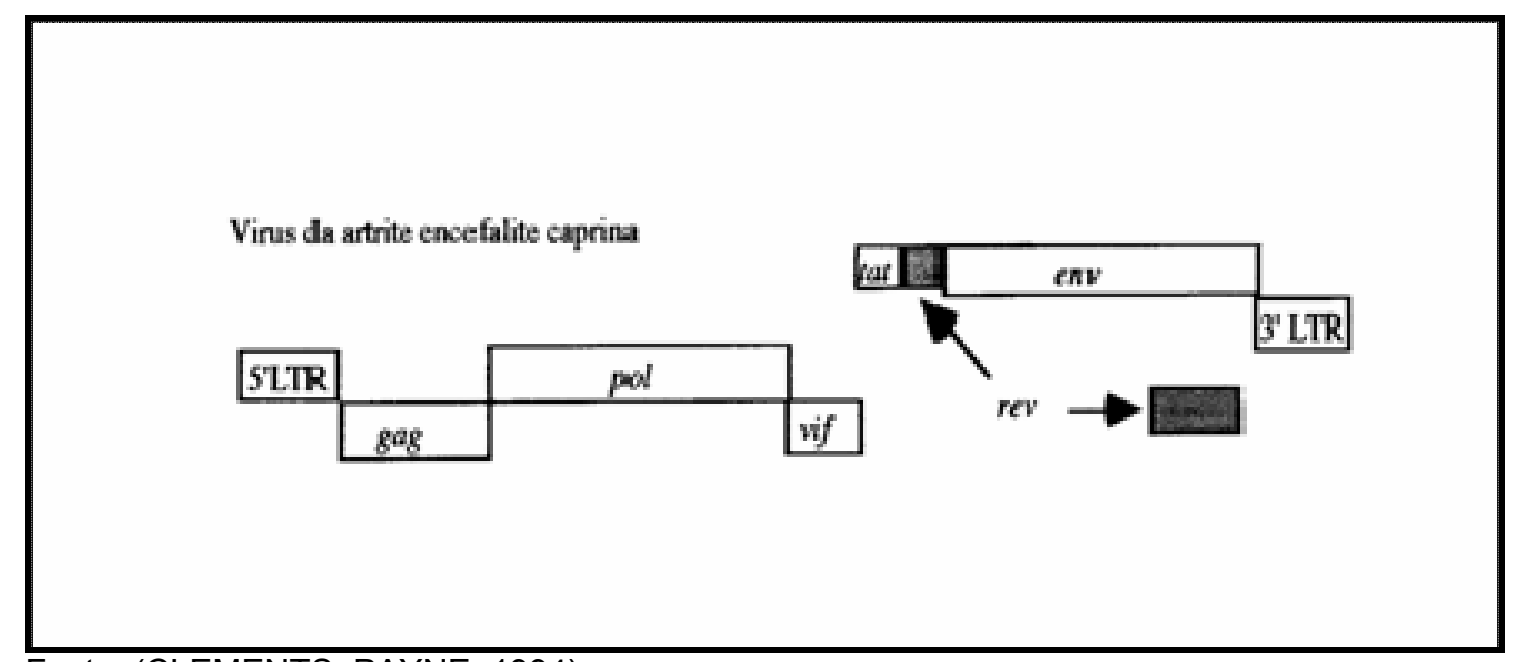

Fonte: (CLEMENTS; PAYNE, 1994)

Figura 2 - Estrutura dos provírus dos Lentivírus CAEV

A partir da transcrição reversa, o RNA genômico dá origem ao DNA proviral, o qual se integra ao genoma das células-alvo, como monócitos, macrófagos e/ou linfócitos T CD4, sendo que a replicação ocorre preferencialmente em algumas populações de macrófagos teciduais, resultando na produção e excreção do vírus infeccioso no leite e provavelmente secreções respiratórias (NARAYAN et al.1992. (Figura 3). 


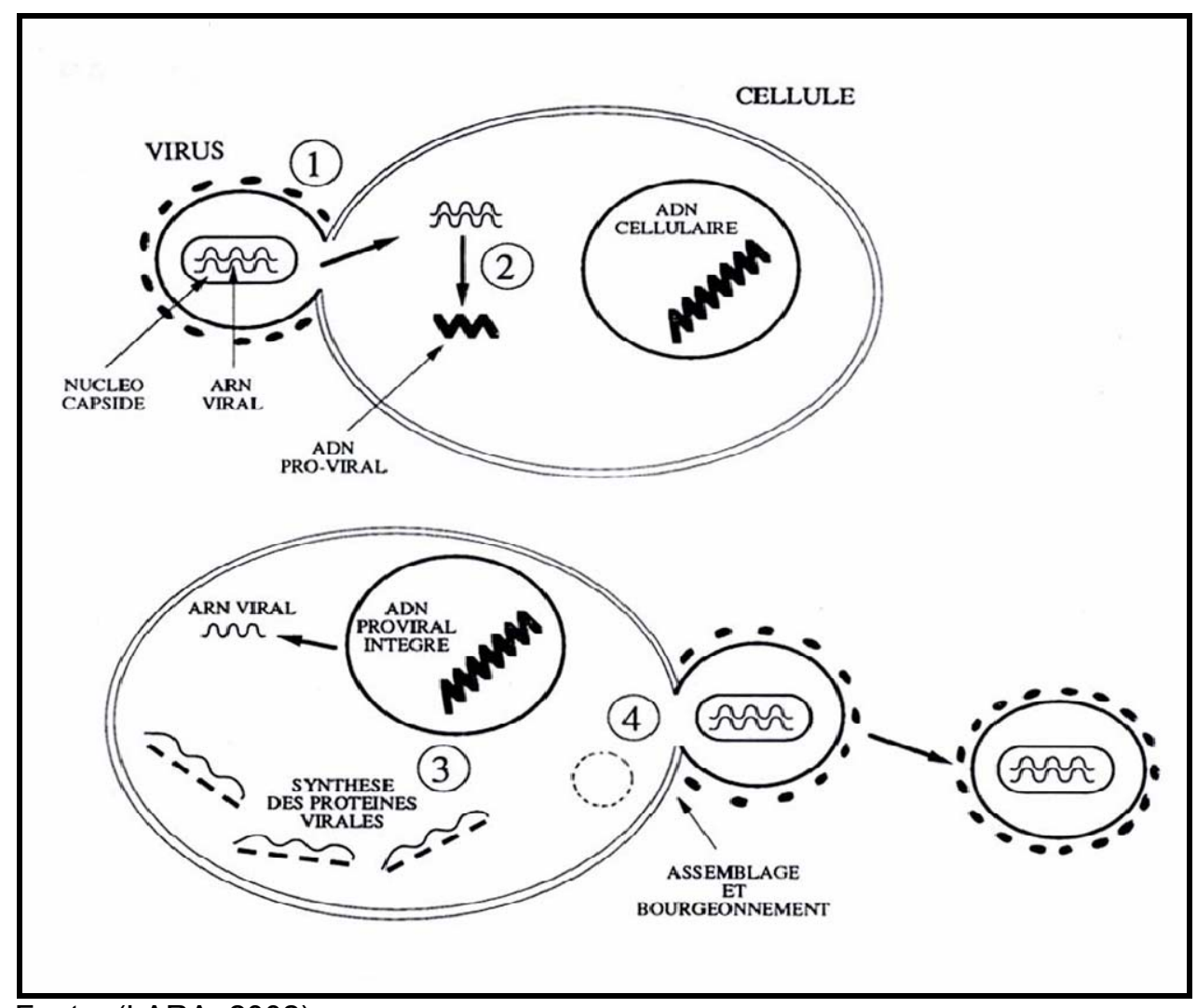

Fonte: (LARA, 2002)

Figura - 3 Esquema da replicação e produção da partícula viral

Beer (1988) descreveu o vírus da CAE como sendo sensível ao éter, clorofórmio, metaperionato, tripsina, formol a 0,04\%, luz ultravioleta, distintas temperaturas e valor de $\mathrm{pH}$ compreendidos abaixo de 5,1, ou acima de 9,4.

$O$ vírus da CAE possui três características gerais que promovem a persistência da infecção em seus hospedeiros. Primeiro, após a transcrição reversa do RNA viral nas células infectadas, o DNA pró-viral se integra no genoma celular, permitindo que o vírus escape dos mecanismos de defesa do hospedeiro e preserve o seu genoma. Segundo alguns autores ele se multiplica em células do sistema imunológico, normalmente responsáveis pela eliminação de células infectadas, assim, o hospedeiro não consegue desenvolver resposta imunológica curativa. Além disso, a restrição da expressão viral sem produção de partículas virais, permite que as células infectadas pelo vírus escapem do sistema imunológico (NARAYAN et al. 1992). E por último, esse vírus acumula alta taxa de mutação durante o processo de replicação, resultando em variabilidade genética e fenotipica escapando, assim, do sistema imunológico do hospedeiro (CHEEVERS et al. 1993). 


\subsection{EPIDEMIOLOGIA}

Segundo Garcia (1993), a CAE já foi descrita em quase todos os continentes do mundo com prevalência mais elevada naqueles países onde há uma caprinocultura mais tecnificada (OIE/FAO, 1997). A tabela a seguir demonstra a distribuição da CAE nos diversos países e reforça o conceito de que a doença é mais intensa em países onde os caprinos são criados de forma intensiva (Tabela 1).

Tabela 1 - Tabela demonstrativa da prevalência da CAE em alguns países.

\begin{tabular}{|ccc|}
\hline País & $\begin{array}{c}\text { Caprinos sorospositivos } \\
(\%)\end{array}$ & Comentário \\
\hline Canadá & 77 & \\
França & 77 & Criação intensiva de caprinos \\
Noruega & 74 & \\
Suiça & 83 & Ilhas (maior possibilidade de controle) \\
EUA & 81 & \\
\hline Inglaterra & 9,5 & Introdução por Importação \\
Nova Zelândia & 8,3 & \\
\hline Kenia & 4,5 & Criação Extensiva de Caprinos \\
México & 5,8 & \\
\hline Peru & 9,3 & \\
\hline Sudão & 0 & \\
Somália & 0 & \\
Africa do Sul & 0 & \\
\hline Fonte: (FRANKE, 1998 $)$ & &
\end{tabular}

Vários estados brasileiros já se mobilizaram no sentido de investigar a real situação de seus rebanhos, quanto à infecção dos caprinos pelo vírus da CAE. Todavia os resultados obtidos têm sido alarmantes, causando grande preocupação aos criadores e aos médicos veterinários, pois os estudos clínicos e epidemiológicos conduzidos nos referidos estados brasileiros têm demonstrado a cada ano o crescente número de animais infectados e a diminuição do número de rebanhos isentos dessa infecção (Tabela 2). 
Tabela 2 - Distribuição das taxas de prevalência da infecção pelo CAEV dos Caprinos no Brasil, utilizando a prova de imunodifusão em gel de ágar, segundo o ano de avaliação, autor da pesquisa e o Estado da ocorrência.

OCORRÊNCIA NO BRASIL

\begin{tabular}{ccccc} 
Ano & Autor & Estado & Prevalência (\%) & População \\
\cline { 2 - 5 } 1986 & MOOJEN et al. & Rio Grande do Sul & 16,0 & 423 \\
1988 & FITTERMAN & Bahia & 52,2 & 23 \\
1993 & D'ANGELINO et al. & São Paulo & 37,5 & 837 \\
1994 & ASSIS e GOUVEIA & Bahia & 12,8 & 204 \\
1994 & ASSIS e GOUVEIA & Minas Gerais & 33,3 & 533 \\
1995 & CUNHA e & Rio de Janeiro & 21,7 & 242 \\
1995 & SARAIVA NETO et al. & Pernambuco & 17,6 & 397 \\
1996 & PINHEIRO et al. & Piauí & 4,4 & 180 \\
1997 & MELO e FRANKE & Ceará & 40,7 & 242 \\
1997 & FERNANDES & São Paulo & 29,8 & 2065 \\
2000 & RAMALHO & Bahia & 29,2 & 692 \\
2001 & PINHEIRO et al. & Ceará & 1,0 & 4019 \\
2002 & LARA & São Paulo & 26,3 & 2800 \\
2004 & LEITE et al. & São Paulo & 43,0 & 1030 \\
\hline Fonte: & NARA & $2002)$ & &
\end{tabular}

Fonte: (LARA, 2002)

Nas várias regiões de criação de caprinos, principalmente de raças leiteiras, tem sido relatados casos clínicos isolados, envolvendo animais infectados pela CAE, esses casos tornam-se mais freqüentes e evidenciados, sobretudo pelo crescente número de caprinos acometidos por artrites, mamites e pneumonias (BIRGEL, 2000).

A infecção dos caprinos pelo vírus da CAE foi considerada como um estado vital permanente, pois o vírus persiste no organismo por toda a vida do animal, havendo a possibilidade da viremia ser permanente, por isso o reservatório e a fonte de infecção da CAE são justamente os animais infectados, que transmitem o agente por meio de secreções ou excreções ricas em células do sistema monocíticofagocitário, fato que facilitaria a transmissão do vírus, através de fômites, agulhas, tatuadores, aplicadores de brincos e material cirúrgico contaminado com sangue de animal infectado. Nos caprinos, a transmissão ocorre geralmente por via digestiva, 
pela ingestão de colostro e leite contaminados (ADAMS et al., 1983; PERETZ et al., 1993). Apesar de ter um significado menor, a transmissão horizontal, por fezes, saliva, secreções respiratória e urogenital e, sobretudo, leite contaminante dos copos das ordenhadeiras mecânicas, tem sido considerada importante, dependendo da situação particular de cada criação (ADAMS et al., 1983; PERETZ et al., 1993). A transmissão vertical pode ocorrer, pois já foi observado a soroconversão de cabritos que foram separados imediatamente após o parto e receberam colostro e leite de vaca pasteurizado (EAST et al. 1993). O aleitamento coletivo adotado em criações intensivas foi relatado como uma forma de manejo que favoreceria a disseminação da infecção viral (ELLIS et al., 1986). A transmissão por via transplacentária ou por monta natural, em caprinos, ainda não foi comprovada de forma insofismável (BIRGEL, 2000; LARA, 2002).

Porém a comprovação da presença do lentivírus no sêmen caprino diagnosticada por Nested-PCR (GREGORY et al. 2007) reforça a possibilidade da transmissão do LVC pela monta natural e pela inseminação artificial (ANDRIOLI et al. 2006). Rowe et al. (1992) observaram maiores taxas de soro-conversão em fêmeas cobertas por machos soropositivos do que naquelas cobertas por machos negativos. Segundo Nash et al. (1995) e Quayle et al. (1997), pouco se conhece sobre fatores que interferem na presença do CAEV no sêmen, porém como os lentivírus infectam monócitos e macrófagos, a presença de inflamações ou infecções no órgão reprodutor poderia desencadear o maior fluxo destas células inflamatórias, resultando em aumento da carga viral no sêmen (ANDRIOLI et al. 2006). Há ainda a possibilidade dos vírus estarem presentes no sêmen na forma livre e como os vírus geralmente não infectam os espermatozóides (NASH et al., 1995; TRAVASSOS et al., 1999), cogitou-se o uso de métodos físicos para separar os espermatozóides do fluido seminal, visando assim, a eliminação dos patógenos. Mas segundo Andrioli et al. (2006) a lavagem do sêmen caprino diminui a carga viral, porém não elimina totalmente o lentivírus caprino no sêmen, assim como o dano testicular é um fator que influencia a presença do lentivírus caprino no sêmen.

Após introdução da CAE em uma criação, a freqüência de animais soropositivos e clinicamente afetados, bem como da intensidade das alterações são bastante variados, dependendo de certos fatores relacionados à intensidade de 
estresse, tipo de nutrição e condições gerais de higiene (CRAWFORD; ADAMS, 1981; PERETZ et al., 1993).

A infecção acomete animais de ambos os sexos, várias raças e idades. Apesar dos relatos de maior prevalência em determinadas raças caprinas e em animais do sexo masculino, não se pode concluir pela maior susceptibilidade racial ou de acordo com o sexo, pois os estudos são de difícil interpretação em relação aos vários fatores ligados ao manejo e origem das diferentes raças (CUTLIP et al., 1988; ROWE; EAST, 1997; LARA, 2002) (Tabelas 3, 4 e 5). Um fator muito importante é o tempo de exposição para a soroconversão. Assim, tem-se observado que a freqüência de soropositivos é maior em caprinos mais velhos (HOUWERS; VAN DER MOLEN, 1987; ROWE et al., 1991; LARA, 2002) (Tabela 7). Em rebanhos com alta taxa de infecção a soroprevalência pode ser bastante elevada entre animais jovens (EAST et al., 1987).

Tabela 3 - Influência do sexo na prevalência da CAE.

$$
\text { Sexo }
$$

\begin{tabular}{ccc} 
& Masculino & Feminino \\
\hline Negativo & 67,7 & 72,1 \\
Positivo & 32,3 & 27,9 \\
\hline Fonte: (LARA, 2002) &
\end{tabular}

Tabela 4 - Influência da raça na prevalência da CAE.

\begin{tabular}{ccccccc} 
& Saanen & Alpina & A.Nubiana & Toggenburg & Bôer & Mestiça \\
\hline Negativo & 72,6 & 88,1 & 36,2 & 44 & 94,1 & 89,3 \\
Positivo & 27,4 & 11,9 & 63,8 & 56 & 5,9 & 10,7 \\
\hline Fonte: (LARA, 2002) & & & & &
\end{tabular}

Tabela 5 - Influência do sistema de criação na prevalência da CAE.

Sistema de criação

Intensivo Semi extensivo

\begin{tabular}{crl}
\hline Negativo & 68,1 & 86,9 \\
Positivo & 31,9 & 13,1 \\
\hline Fonte: (LARA, 2002)
\end{tabular}


Tabela 6 - Influência da idade em meses na freqüência de soropositivos em caprinos.

\begin{tabular}{lrcccccc}
\hline $\begin{array}{c}\text { Idade } \\
\text { (meses) }\end{array}$ & $<6$ & 6 a 12 & 12 a 24 & 24 a 36 & 36 a 48 & 48 a 60 & $>60$ \\
Negativo & 81,6 & 84,8 & 79 & 72,1 & 65,2 & 67,3 & 51,6 \\
& 18,4 & 15,2 & 21 & 27,9 & 34,8 & 32,7 & 48,4 \\
Positivo & 18,4 & & & & &
\end{tabular}

Fonte: (LARA, 2002)

Para Guedes et al. (2001), a infecção e/ou soropositividade não estão obrigatoriamente relacionadas com a presença de sinais clínicos, uma vez que apenas $35 \%$ dos animais infectados apresentam algum sinal característico. Relata ainda, que apesar da soroprevalência da CAE em um rebanho poder atingir $90 \%$, a maioria dos animais infectados não desenvolve sintomatologia clínica. A ocorrência de alguns rebanhos com quase a totalidade dos animais infectados tem sido explicada e atribuída ao fato da infecção poder persistir por toda a vida do animal e apresentar, inúmeras vezes uma evolução assintomática, ou não diagnosticada, tornando esses animais fontes de infecção (NARAYAN et al.1992). A doença pode levar vários meses e até anos para se manifestar; portanto os animais nessas condições representam um importante elo de transmissão, pois aparentemente são sadios, mas são portadores do vírus e podem transmiti-lo aos demais animais.

Com a evolução da caprinovinocultura e o constante crescimento do mercado, houve a necessidade dos órgãos públicos dispensarem uma maior preocupação com aspectos sanitários desses animais, assim, a produção de caprinos e ovinos deve ser fundamentada em sistemas de exploração que possam garantir melhores condições sanitárias para estes animais, através de medidas de biosegurança e de exames diagnósticos confiáveis e acessíveis.

Através da Instrução Normativa $N^{\circ} 87$ da Secretaria de Defesa Agropecuária, de 10 de dezembro de 2004, foi aprovado o Regulamento Técnico do PNSCO. O controle e erradicação das doenças de caprinos e ovinos, por meio de ações sanitárias e de vigilância epidemiológica definidas pelo DDA e executadas pelos serviços oficiais e médicos veterinários cadastrados, estão entre os objetivos do Programa. 
Dentre as estratégias de atuação, serão destacadas: o cadastro de estabelecimentos, o controle de trânsito de animais, a certificação de estabelecimentos, o cadastramento de Médicos Veterinários do setor privado e o credenciamento de laboratórios para realização de exames diagnósticos das doenças de controle oficial.

Atualmente, o PNSCO encontra-se em fase de estruturação. Foi formado um Comitê Técnico Científico, composto de profissionais dos diversos setores da caprino e ovinocultura, com o objetivo de dar suporte técnico as decisões do Programa. As propostas sanitárias estão em fase de conclusão e estão sendo disponibilizadas por meio de Consulta Pública, de maneira a permitir a participação de todos setores interessados (MAPA, 2007).

\subsection{PATOGENIA}

Os lentivírus são introduzidos no organismo dos animais susceptíveis geralmente por via digestiva ou respiratória (HUSSO et al. 1988). Em seguida o vírus infecta as células do sistema monocítico-fagocitário, produzindo a infecção persistente do hospedeiro. Uma vez dentro dessas células, o RNA gênomico dá origem ao DNA próviral, sob a ação da enzima viral transcriptase reversa. O produto se integra ao genoma das células-alvo, ou seja, monócitos e macrófagos, constituindo o chamado provírus.

Processos inflamatórios em outros locais promovem o recrutamento desses macrófagos infectados; desse modo, facilitam a disseminação do vírus ao pulmão, SNC, articulações e à glândula mamária.

Os mecanismos desenvolvidos pelos patógenos para persistência da infecção frente à resposta imune incluem: capacidade dos monócitos de conter provírus integrado em seu genoma sem ser detectado pelo sistema imune, pois a expressão do gene viral só é ativada quando os monócitos maturam para macrófagos (BRODIE et al. 1995); para capacidade de infectar persistentemente macrófagos, sem causar lise celular, podendo disseminar o vírus no próprio hospedeiro, sem a produção de partículas virais, através do contato com outras 
células (NARAYAN et al. 1990); interrupção do ciclo viral; replicação de variantes antigênicos na presença de anticorpos neutralizantes (McGUIRE et al. 1988, CHEEVERS et al. 1993); a produção insuficiente de anticorpos neutralizantes e produção de interferon, que diminui o índice de replicação e favorece a persistência do estímulo antigênico (KLEVJER-ANDERSON; McGUIRE 1982, NARAYAN et al. 1984, ZINK et al. 1987, BERTONI et al. 1994, CHEEVERS et al. 1993 apud CASTRO, 1998). Por outro lado, a presença de ácido salicílico na superfície da partícula viral dificulta a ação dos anticorpos neutralizantes (HUSSO et al. 1988), e a alta mutabilidade do agente que pode resultar em variantes antigênicas, funcionam como mecanismos de escape da resposta celular e humoral (KNOWLES et al. 1990, CHEEVERS et al. 1993, LICHTENSTEIGER et al. 1993 apud CASTRO, 1998).

A replicação viral é seguida pela produção de anticorpos e citocinas que participam do desenvolvimento das alterações imunopatológicas que ocorrem nos órgãos-alvo (DeMARTINI et al. 1993, LEGASTELOIS et al. 1996a). A produção persistente de antígenos virais e interação quer seja na forma de proteína livre ou expressa na célula durante a infecção, e os anticorpos, formando imunocomplexos, contribui para a progressão da doença (KNOWLES et al. 1990, BERTONI et al. 1994, MDURVWA et al. 1994, BRODIE et al. 1995, PERRY et al. 1995 apud CASTRO, 1998). As alterações patológicas que ocorrem nas infecções causadas por lentivírus são, na maior parte, mediadas indiretamente pela resposta imune do hospedeiro, resultado da alteração da atividade ou produção de citocinas, como IL-1 e INF pelos monócitos (CASTRO et al. 1998). Já foi demonstrada a presença de elevados níveis de IFN no líquido sinovial de caprinos naturalmente infectados (CASTRO et al. 1998). O IFN é responsável pelo desenvolvimento da resposta linfoproliferativa por induzir a expressão de antígenos (ZINK et al. 1987). É provável ainda que infecções oportunistas possam induzir a secreção de fatores celulares que modulem a replicação viral e a manifestação da infecção como doença clinicamente aparente (ELLIS et al. 1994, LUJÁN et al. 1994). Finalmente, a freqüência e a severidade das lesões parecem estar associadas a fatores do genoma do hospedeiro (RUFF; LAZARY, 1988, DOLF; RUFF, 1994, CONCHA-BERMEJILLO et al. 1996) e da amostra viral (CHEEVERS et al. 1988, LAIRMORE et al. 1988). 


\subsection{ASPECTOS CLÍNICOS E ANATOMO-HISTOPATOLÓGICOS}

A infecção pelo lentivírus, geralmente persistente e assintomática, pode causar afeç̧ão multissistêmica, de evolução geralmente crônica, com agravamento progressivo das lesões, perda de peso e debilidade até a morte (CALLADO et al. 2001). O vírus causador da CAE pode provocar quatro formas clínicas da doença: articular (artrite crônica), mamária (mamite endurativa em cabras adultas), pulmonar (pneumonia progressiva aguda) e nervosa (leucoencefalomielite). Além dessas formas, há registro, em animais soropositivos, de alterações inflamatórias nos rins, proliferação de células linfóides no baço e linfonodos (GONZALEZ et al. 1987) e infiltrações mononucleares do endométrio (ALI, 1987). No útero não há alterações macroscópicas visíveis. Na histologia, observa-se infiltração mononuclear, com predominância de linfócitos envolvendo principalmente o endométrio, sem aparente envolvimento do miométrio e da serosa, a infiltração linfocitária é focal ou difusa, sendo mais abundante na camada subepitelial.

\subsubsection{Forma Clínica Articular}

As primeiras informações sobre uma enfermidade enzoótica articular de caprinos, com descrição dos sinais clínicos e das alterações anatomopatológicas, foram apresentadas na Suíça por Stünzi et al. (1964). A doença, denominada artrite crônica endêmica dos caprinos, foi considerada como de origem hereditária. $\mathrm{Na}$ descrição das alterações da articulação do carpo, observaram-se aumento de volume circular da articulação. As lesões iniciavam-se na face extensora da articulação, atingindo uni ou bilateralmente os membros anteriores. (Figura 4) 


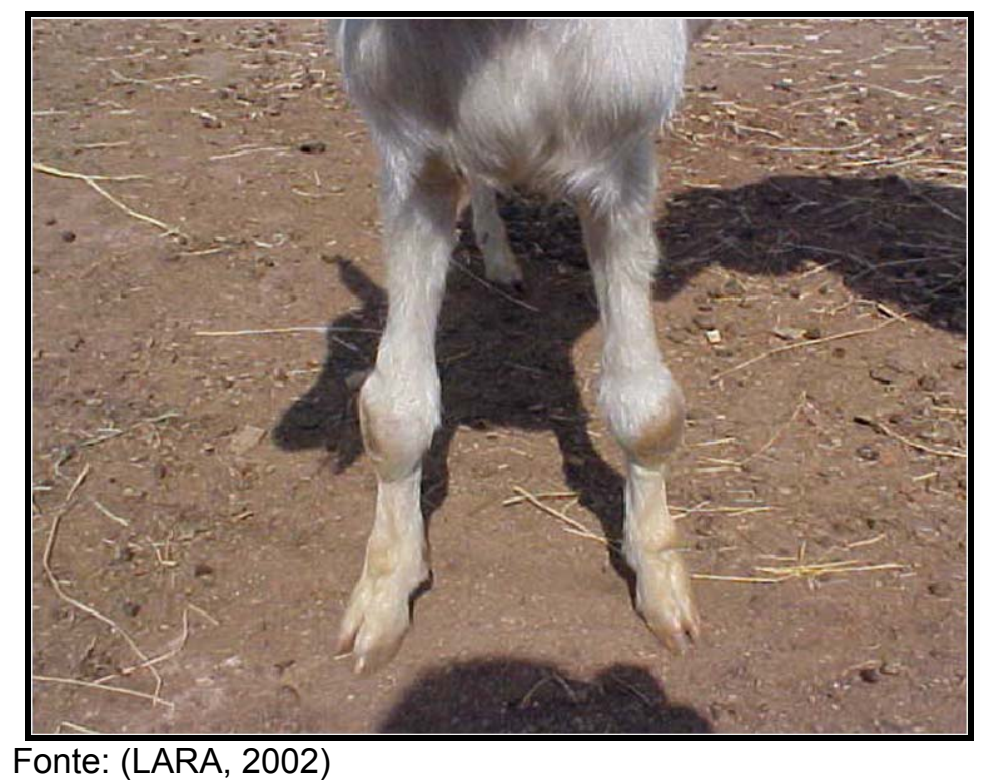

Figura 4 - Carpos aumentados de volume em animal CAE positivo.

A forma clínica articular foi caracterizada como uma doença de desenvolvimento insidioso, pois geralmente, progride lentamente, de meses a anos, podendo aparecer repentinamente em alguns animais, permanecendo a seguir estática. Em outros casos, após a instalação dos sintomas, a evolução e o agravamento das manifestações progrediam rapidamente, entretanto, em alguns desses casos observou-se evolução lenta, mas progressiva, podendo ser acompanhada durante vários anos (NARAYAN; CORK, 1990).

A forma clínica articular, caracterizada por artrite progressiva, foi descrita em animais adultos com mais de seis meses de idade (EAST, 1996), sendo mais freqüente em animais de dois a nove anos de idade (NARAYAN; CORK, 1990). As articulações do carpo foram consideradas as mais afetadas. Com menor freqüência ocorreu em outras articulações como a do jarrete, a patelar e a atlanto-occiptal (LARA et al. 2005) (Figura 5). 


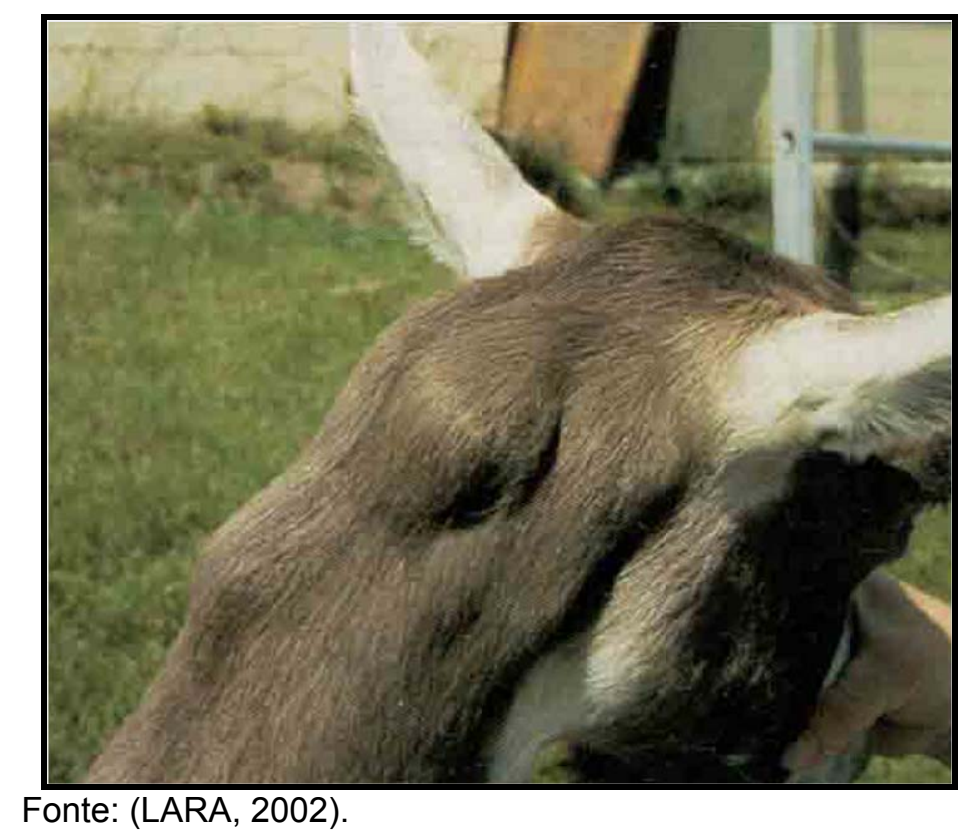

Figura 5 - Articulação atlanto-occipital em animal CAE positivo.

Com o evoluir da doença observou-se: aumento de volume da articulação, caracterizado por claudicação intensa, dificuldade do animal para deitar e para se erguer e, conseqüentemente, haveria evidente emagrecimento. O líquido sinovial, que foi descrito como menos viscoso do que de articulações sadias e sua coloração variaria do amarronzado ao avermelhado, com redução na proteína e significativo aumento do número de células sinoviais 1.000 a 20.000 células/ mm3, com $90 \%$ de células mononucleares das quais $60-70 \%$ são linfócitos (GREGORY et al. 2006).

$\mathrm{O}$ aumento de volume observado, na maioria das vezes o aumento da região, se daria pela hiperplasia da cápsula articular e dos tecidos tendinosos e conjuntivo associados à articulação comprometida, dor articular. Esses motivos causariam uma restrição dos movimentos, determinando atitudes e aprumos anormais, como por exemplo, genuflexão temporária ou permanente ao locomoverse apoiando os membros anteriores sobre a face extensora da articulação do carpo (Figura 6). Também se demonstrou a ocorrência da anquilose da articulação e calosidade da superfície permanentemente fletida da articulação ou erosões na pele que a recobre (EAST, 1996). As radiografias das articulações precocemente afetadas revelam tumefação do tecido mole anteriormente ao carpo e por vezes ao tarso. Esse quadro tem evolução pelo surgimento de depósitos calcificados no tecido periarticular, cápsulas articulares, ligamentos, tendões e bainhas tendinosas. As alterações ósseas são branda reação periosteal, mineralização periarticular e 
irregularidade das superfícies ósseas proximais e distais à articulação (SMITH, 1993) (Figura 7).

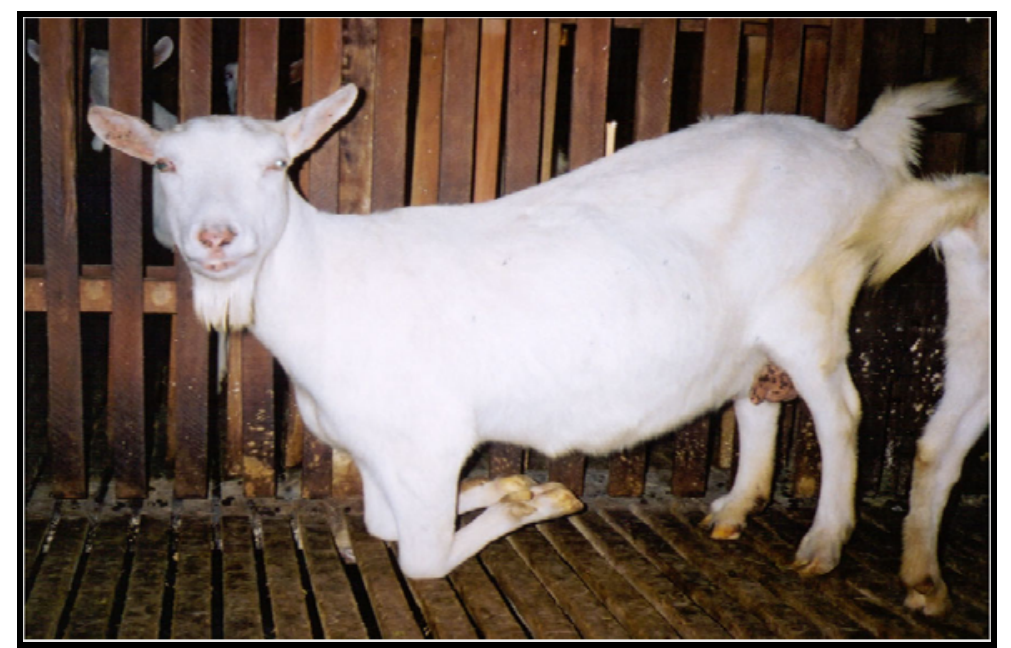

Fonte: (LARA, 2002).

Figura 6 - Animal CAE positivo mostrando apoio em carpos.

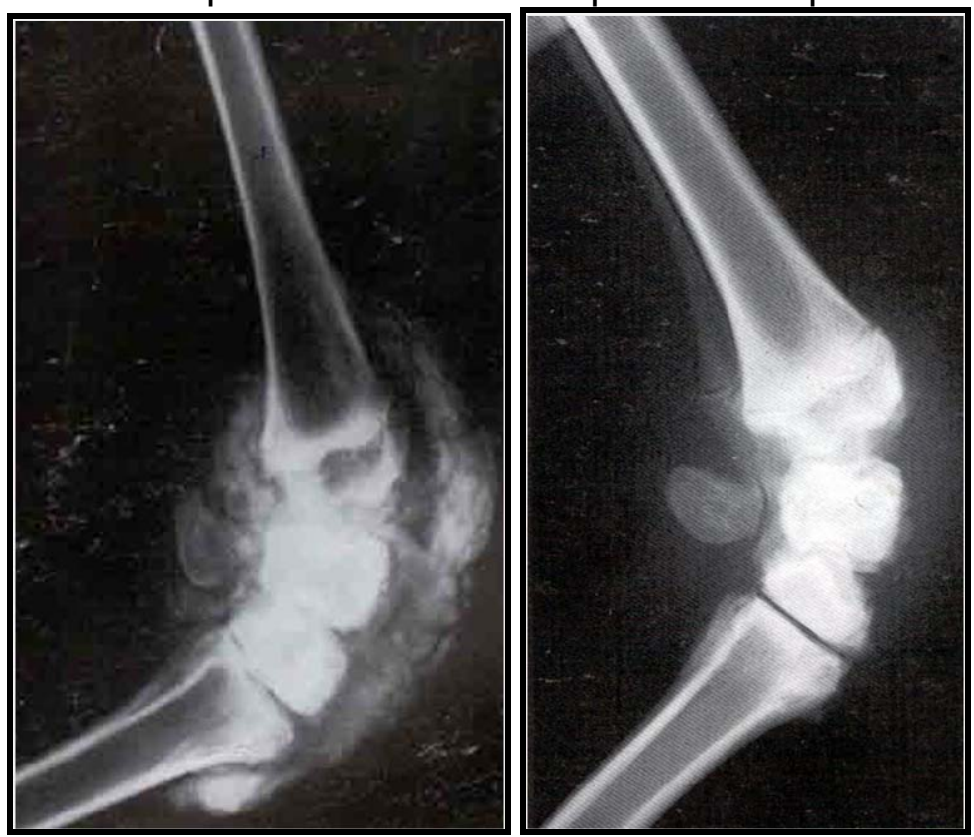

Fonte: (LARA, 2002)

Figura 7 - Radiografia de carpo em animal CAE positivo com artrite à esquerda e outro normal à direita.

\subsubsection{Forma Clínica Mamária}

Na glândula mamária de cabras infectadas, natural ou experimentalmente, descreveu-se o endurecimento gradativo e difuso do parênquima resultando em 
assimetria das metades do úbere, quando observado por inspeção com visão posterior (PERK, 1988). Smith; Cutlip (1988); Lerondelle et al. (1995, 1999) afirmaram a ocorrência da diminuição da produção láctea nas cabras acometidas pela $\mathrm{CAE}$ e a mamite conseqüente desenvolvia-se de forma difusa, sendo caracterizada por endurecimento progressivo não edematoso ou de forma nodular, com a presença de vários nódulos de consistência dura, que confluem para determinar um endurecimento difuso do parênquima mamário. As alterações histopatológicas evidenciaram infiltrações perivasculares e do próprio parênquima glandular por células mononucleares, por linfoproliferação e hiperplasia dos folículos linfóides e que muitas vezes evoluem para calcificação e necrose dos alvéolos (ZWAHLEN et al., 1983; GONZALES et al., 1987; CHEEVERS; McGUIRE, 1988; PERK, 1988 apud BIRGEL JUNIOR et al. 2005). A diminuição da produção leiteira de cabras infectadas pelo vírus da CAE foi demonstrada também por Bohland (1998) no Brasil, sendo que as cabras sadias produziam entre 25 e $31 \%$ de leite a mais em relação aos animais infectados. Os caprinos sadios apresentavam lactações até $17 \%$ mais longas do que os infectados. Relacionando a ocorrência de mamite endurativa, Birgel Junior et al. (2005) observou que do total de 97 glândulas palpadas, o endurecimento difuso da glândula mamária foi diagnosticado em 19,68\% das cabras infectadas pelo vírus da CAE, enquanto Lara et al. (2005) na sua pesquisa sobre as formas clínicas da artrite encefalite caprina encontrou $6,6 \%$ de cabras sororeagentes com mamite endurativa. Segundo Birgel Junior. et al. (2005) a infecção pelo referido vírus determina significativa influência na composição físicoquímica e celular do leite de caprinos, sendo que os valores de eletrocondutividade, os teores de cloretos e a contagem de células somáticas foram maiores nas cabras infectadas pelo vírus com ou sem sinais de endurecimento difuso da mama; enquanto os valores de proteína, gordura e sólidos totais foram menores somente no grupo de cabras infectadas pelo vírus com sinais de endurecimento difuso da mama.

\subsubsection{Forma Clínica Pulmonar}

A apresentação pulmonar é rara e de menor gravidade entre caprinos. Os sintomas são tosse, dispnéia após exercícios físicos, taquipnéia, macicez pulmonar, 
estertor úmido à auscultação e comprometimento do estado geral (CONCHABERMEJILLO, 1997). As alterações macroscópicas encontradas são aderências pleurais, pulmões pesados e firmes à palpação e áreas de coloração róseaacinzentadas (ROBINSON; ELLIS, 1984; NARAYAN; CORK, 1985; CUTLIP et al., 1988; PERETZ et al., 1993; PEREIRA, 1995 apud CALLADO et al. 2001). Os achados microscópicos são pneumonia intersticial e broncointersticial (ROBINSON; ELLIS, 1984; NARAYAN; CORK, 1985; CUTLIP et al., 1988; PERETZ et al., 1993; MORNEX et al., 1994; PEREIRA, 1995 apud CALLADO et al. 2001)

\subsubsection{Forma Clínica Nervosa}

A forma nervosa é de menor importância, tendo sido relatada em cabritos, de um a quatro meses de idade ou, menos freqüentemente, em caprinos mais velhos, em associação com a forma articular. Os animais, mesmo mantendo o apetite e a atividade mental normais, apresentam ataxia e paresia uni ou bilateral dos membros posteriores, que evolui para tetraparesia (NARAYAN, CORK, 1990) (Figura 8). A marcha do animal é curta e inconsciente, seguida por fraqueza e por fim decúbito. Nos animais que ainda têm capacidade de ficar em pé pode haver perda acentuada da propriocepção em uma das pernas posteriores. O envolvimento cerebral se manifesta por cabeça pendente, torcicolo e andar em círculos (BLOOD, 1991). As lesões microscópicas são meningoencefalomielite e desmielinização (CORK et al. 1974; NORMAN; SMITH 1983; GONZALEZ et al. 1987; CUTLIP et al. 1988; CONSTABLE et al. 1996 apud CALLADO et al. 2001). As lesões macroscópicas geralmente não ocorrem, podendo ocasionalmente haver áreas focais de coloração marrom-clara na substância cinzenta da medula oblonga e medula espinhal. 

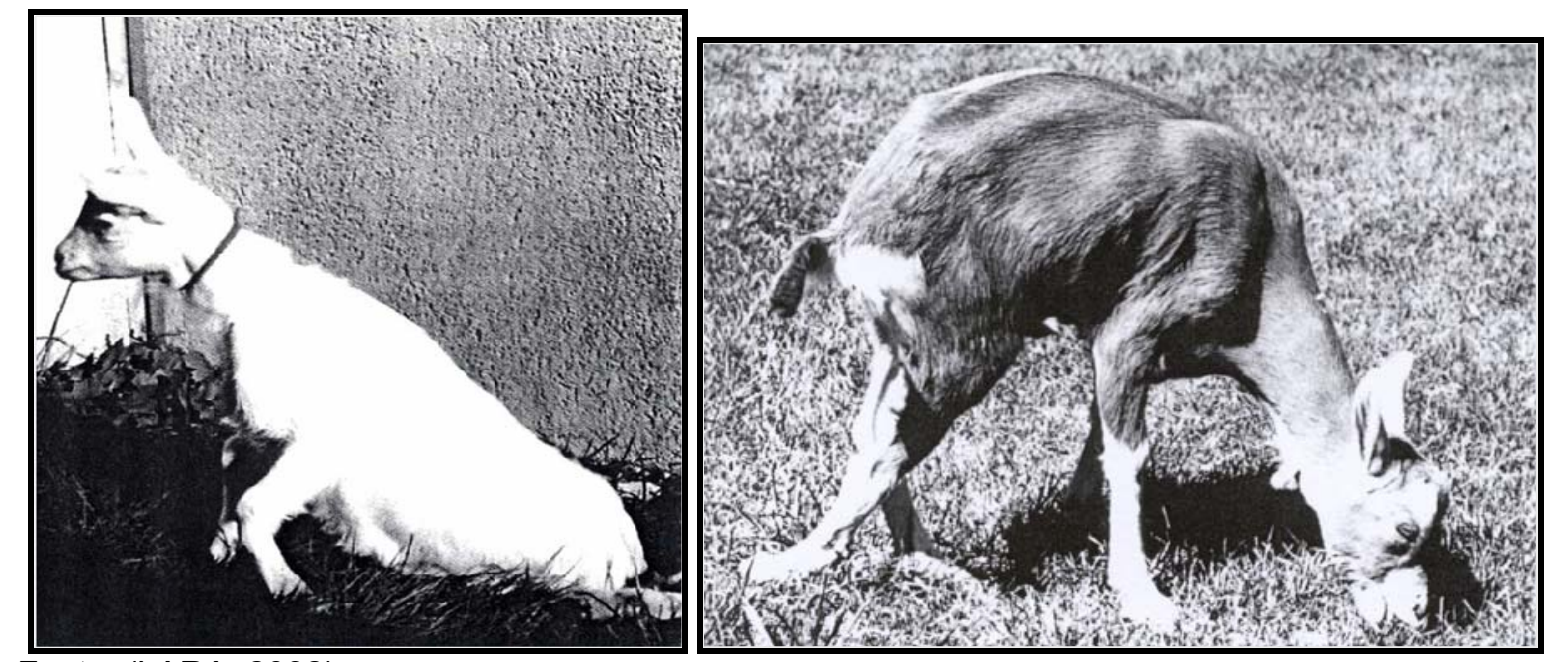

Fonte: (LARA, 2002)

Figura 8 - Animais CAE + apresentando paresia dos membros posteriores uni ou bilateral.

\subsection{DIAGNÓSTICO}

Os animais infectados pelo vírus da CAE nem sempre apresentam alterações clínicas evidentes, por isso estabeleceu-se ser importante que o diagnóstico seja baseado, tanto nos antecedentes e no histórico, no exame físico do doente, como também em resultados de exames laboratoriais, principalmente, nas provas imunosorológicas para detecção de anticorpos virais (CRAWFORD; ADAMS, 1981).

Naqueles animais que apresentarem forma clínica, deve-se atentar para realizar o diagnóstico diferencial com outras enfermidades. O diferencial da forma articular deve ser feito com Micoplasmose, Clamidiose, traumas osteo-articulares e outras causas bacterianas como Staphylococcus sp e Streptococcus sp. Enquanto que o diferencial da forma nervosa deve ser feito com Listeriose, traumatismos, Polioencefalomalácia, Toxoplasmose, Deficiência de cobre e Scrapie.

A avaliação laboratorial da infecção pelo vírus da CAE pode ser feita por técnicas diretas ou indiretas. A detecção direta da presença do vírus pode ser realizada tanto pelo isolamento em cultura celular e evidenciação do vírus em microscopia eletrônica (Figura 9) e da hibridização in situ. Por outro lado, o diagnóstico direto da infecção, pelo isolamento e identificação do agente não é rotineiramente empregado por ser demorado e bastante dispendioso. Alternativamente, tem-se utilizado, em condições ainda experimentais, porém com grandes possibilidades de uso rotineiro, a reação em cadeia de polimerase (PCR), 
para amplificação do DNA proviral ou do DNA sintetizado in vitro pela RT (RT-PCR), a partir do RNA viral (KNOWLES, 1997).

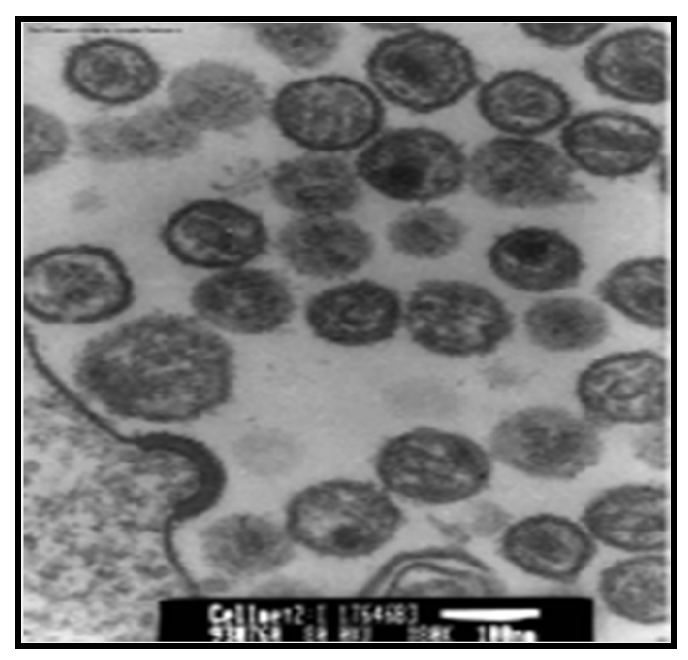

Figura 9 - Evidenciação do vírus em microscopia eletrônica

A determinação indireta da infecção pelo vírus da CAE se faz pela detecção da presença de anticorpos por técnicas soro-imunológicas como: imunodifusão em gel de ágar (IDGA) (Figura 10); ensaio imunoenzimático (ELISA)(Figura 11); imunofluorescência indireta (IFI) (Figura 12) e "Western Blot" (REISCHAK, 2000). Devido à praticidade na colheita das amostras e ao custo reduzido, da realização das provas diretas, os métodos sorológicos foram amplamente utilizados para auxiliar o diagnóstico da infecção pelo vírus da CAE.

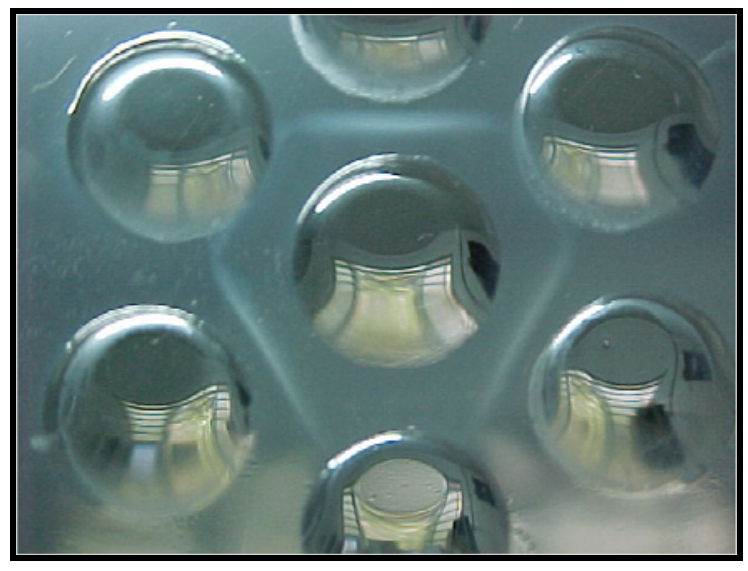

Figura 10 - Determinação indireta por imunodifusão em gel de agar (IDGA) 


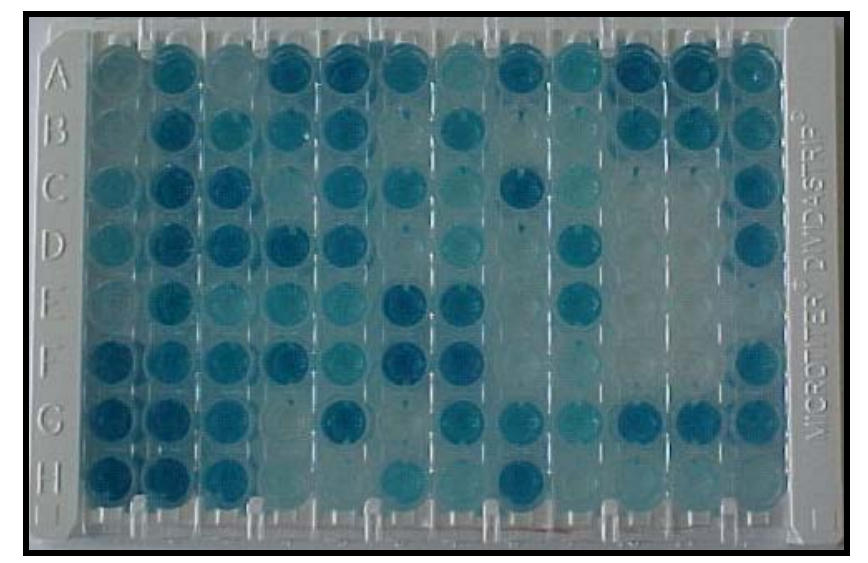

Figura 11 - Determinação indireta por ensaio imunoenzimático (ELISA)

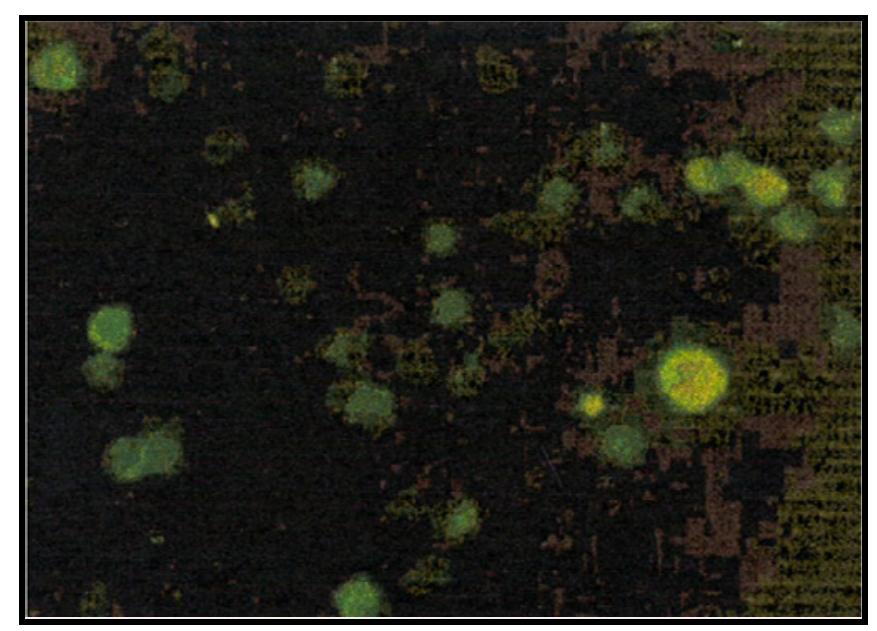

Figura 12 - Detecção da presença de anticorpos por imunofluorescência indireta (IFI)

Dentre os testes sorológicos disponíveis, o IDGA tem sido amplamente utilizado (ADAMS; GORHAM, 1986; SIMARD; BRISCOE, 1990; KNOWLES et al., 1994; ABREU et al., 1998). Segundo Abreu et al. (1998), o IDGA é um teste laboratorial muito difundido e utilizado, que tem grande aceitação na execução de testes de rebanhos devido ao custo relativamente baixo, devido a boa sensibilidade e especificidade, além da praticidade de execução de leitura. O material utilizado para diagnostico laboratorial, é o soro sangüíneo, que pode ser armazenado desde que seja congelado. Seu envio para o laboratório, deve ser em caixa de isopor com gelo, mantendo a temperatura entre 2 e $8^{\circ} \mathrm{C}$. O antígeno comumente utilizando no diagnóstico sorológico da CAE pelo IDAG é produzido a partir do vírus do MaediVisna (MVV) importado, por sua semelhança antigênica (GUEDES et al. 2001). A 
escolha do antígeno para pesquisa de anticorpos para CAE tem sido motivo de controvérsia, pois embora haja recomendação para o emprego do MVV recentemente tem sido demonstrado que a IDGA com glicoproteínas do CAE é mais sensível que com o antígeno do vírus MVV (ABREU et al. 1998).

Entretanto, devido a maior sensibilidade e possibilidade de quantificação e automação, vários ensaios imunoenzimáticos têm sido desenvolvidos para pesquisa de anticorpos séricos, usando-se antígenos CAEV (SCHROEDER et al., 1985; ARCHAMBAULT et al., 1988; HECKERT et al., 1992 apud CASTRO, 1998), maedi visna (HOUWERS et al., 1982; VITU et al., 1982; HOUWERS; SHAAKE, 1987; ZANONI et al., 1989 apud CASTRO, 1998), ou proteína recombinante de CAEV (RIMSTAD et al., 1994; ALFONSO CLAVIJO; THORSEN, 1995 apud CASTRO,1998) ou de maedi-visna (KWANG et al., 1995 apud CASTRO, 1998). O uso de proteínas recombinantes tem causado problemas de resultados falso positivos, o que tem resultado na substituição desse tipo de antígeno pelos do vírus completo (ZANONI et al., 1994). Também tem sido adaptado um ELISA para pesquisa de anticorpos no leite ou colostro, sem grandes vantagens em relação aos testes com soros (MOTHA; RALSTON, 1994).

Adams et al. (1980), em pesquisa delineada para avaliar a resposta imune de cabras infectadas experimentalmente com o vírus da CAE, compararam os resultados obtidos pelas técnicas de IDGA e ELISA, verificando que após o aparecimento dos anticorpos anti-vírus da CAE, estes aumentavam rapidamente e que ambos os testes empregados puderam detectar os resultados positivos ao mesmo tempo. Embora tivesse existido boa correlação, entre os dois testes empregados, os pesquisadores consideraram o ELISA mais sensível.

Os valores de sensibilidade e especificidade obtidos por Lara et al. (2002) para o teste de ELISA, concordaram com os relatados por Heckert et al. (1992), que obtiveram 98,3\% e 97,9\%, respectivamente para sensibilidade e especificidade. Estes valores epidemiológicos também foram semelhantes aos demonstrados por Saman et al. (1999), que comparando a detecção de anticorpos anti-vírus da CAE por ELISA e pela IDGA, obtiveram valores de sensibilidade de $99,4 \%$ e de especificidade de 99,3\%.

Tanto o ELISA, como a IFI, utilizadas para a detecção de anticorpos antivírus da CAE, demonstraram concordância nos resultados que estimaram a sensibilidade, especificidade e concordância, quando contrastadas com a prova de 
IDGA, considerada como teste de referência, podendo serem utilizadas em levantamentos clínico-epidemiológicos para determinação das prevalências da doença e/ou da infecção determinada pelo vírus da CAE.

Devido à restrição da expressão gênica, ou durante a fase precoce da infecção, vários animais infectados por LVPR são soronegativos por períodos bastante variados. Nesses casos a PCR tem se apresentado como potencial alternativa na identificação de animais com sorologia negativa ou dúbia (RIMSTAD et al., 1993; CHEBLOUNE et al., 1996) (Figura 13). Vários sistemas, com iniciadores derivados das sequências dos genes gag ou pol, foram desenvolvidos para detecção de DNA proviral ou RNA viral em leucócitos, células do leite, de lavado brônquioalveolar e do líquido sinovial (REDDY et al., 1993; RIMSTAD et al., 1993; BARLOUGH et al., 1994; LEROUX et al., 1995, 1997b; CHEBLOUNE et al., 1996; RUSSO et al., 1997 apud CASTRO, 1998). Como alternativa para aumentar a quantidade do produto amplificado e permitir sua visualização pela coloração com brometo de etídio, tem-se usado iniciadores internos à região inicialmente amplificada (BARLOUGH et al., 1994; LEROUX et al., 1995 apud CASTRO, 1998), pois geralmente os produtos amplificados só são detectados após hibridização com sonda específica do fragmento do gene que se deseja amplificar (REDDY et al., 1993; RIMSTAD et al., 1993; BARLOUGH et al., 1994; CHEBLOUNE et al., 1996; LEROUX et al., 1995, 1997b; RUSSO et al., 1997 apud CASTRO, 1998). Outro método de detecção de ácidos nucleicos virais, porém de uso limitado, é a hibridização in situ (BRODIE et al., 1995). 


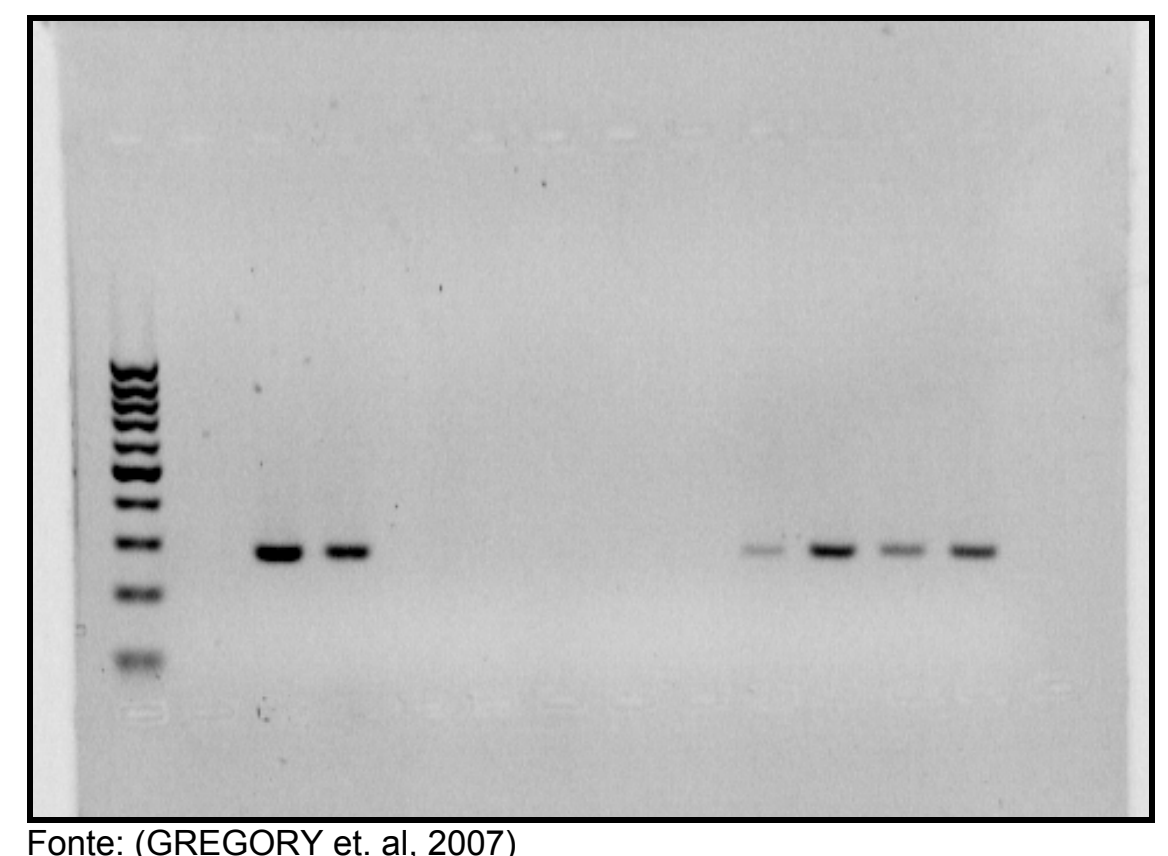

Figura 13 - Eletroforese em gel de agarose após reação de PCR do DNA proviral do CAEV

\subsection{CONTROLE E PROFILAXIA}

Atualmente, os programas de controle ou erradicação da infecção por CAEV têm sido adotados em vários países, geralmente de adesão voluntária, baseados no teste periódico dos animais, com separação ou eliminação dos positivos, e uso de certas práticas de manejo para prevenção da disseminação do agente (OIE/FAO, 1997). Nos plantéis suspeitos ou sabidamente positivos, algumas recomendações têm sido adotadas, com resultados bastante variados.

Não há tratamento específico para a infecção pelo CAEV e não há vacina (RIBEIRO, 1997) por esses motivos se torna de suma importância sua prevenção, evitando comprar animais de criatórios onde ela ocorre e nunca adquirindo animais com sintomas clínicos (RIBEIRO, 1997). Recomenda-se o controle da infecção realizando os testes sorológicos periódicos (uma a duas vezes por ano) nos caprinos acima de 9 meses de idade (RIBEIRO, 1997). Uma vez introduzida a doença no plantel, deve-se adotar algumas medidas para seu controle e posteriormente sua erradicação. A implantação e o acompanhamento do plano de saneamento nas propriedades devem ser realizados por um Médico Veterinário que esteja em contato com um centro que realize o diagnóstico sorológico da CAE (FRANKE, 1998b). 
Segundo Garcia (1993), em primeiro lugar deve ser feito um levantamento da situação do rebanho por meio de exames sorológicos. Em casos de prevalência baixa de animais soropositivos (5 - $10 \%$ ), recomenda-se a erradicação do problema com o abate desses animais. Em uma prevalência mais alta (acima de 10\%) pode-se optar pela manutenção dos animais de elevado valor zootécnico, desde que sejam identificados com uma marca de fácil visualização.

É necessário adotar um cuidado especial com os animais recém nascidos em criações onde ocorre a CAE, pois como visto anteriormente o colostro é a principal via de transmissão. Desta forma, o cabrito não deve mamar na mãe sendo separado logo após o parto e assim, criado livre da infecção (BLOOD et al. 1991). Segundo Ribeiro (1997), o colostro da cabra nunca deve ser fornecido cru, há necessidade de tratá-lo termicamente aquecendo-o a $56^{\circ} \mathrm{C}$ por uma hora. Também se pode utilizar colostro de outras espécies ou sucedâneo de colostro e colostro em pó. O colostro de outras espécies como, por exemplo, a bovina certamente não transmite a $\mathrm{CAE}$, porém pode transmitir doenças típicas de bovinos como a brucelose e tuberculose. Além disso, devemos estar cientes de que a transmissão de imunidade é menos eficiente. O sucedâneo de colostro deve ser preparado com sangue de animal comprovadamente sadio, caso contrário este irá disseminar doenças para os cabritos. Existe também a possibilidade de formar um banco de colostro, onde as cabras fornecedoras devem ser testadas pela técnica de PCR a fim de confirmar a inexistência de anticorpos para a CAE.

Para Ribeiro (1997), a formação de dois rebanhos, um com caprinos positivos e outro com negativos, mantidos separadamente, e a eliminação gradativa dos caprinos afetados é uma medida eficaz no controle da infecção. Os cabritos negativos devem ficar permanentemente isolados por uma faixa de no mínimo 1,8 m de largura com relação aos caprinos soropositivos. Não se deve permitir que os animais compartilhem comedouros e bebedouros. Cabras soro negativas devem ser montadas por bodes CAE negativos (SMITH, 1993).

Recomenda-se ter cuidados especiais com as agulhas, seringas e materiais cirúrgicos que devem ser criteriosamente esterilizadas dando preferência a materiais descartáveis. Quando não possível a utilização desses, é necessário desinfetá-los entre o uso de um animal e outro. Materiais como canivetes e tatuadores devem ser mergulhados em água fervente antes de serem utilizados em outros animais. 
Para Garcia (1993) uma linha de ordenha deve ser instituída, pois, embora remota, há a possibilidade de transmissão da CAE, assim devemos ordenhar primeiro os animais negativos e por fim os animais positivos. Por último, se deve levar em conta a presença da CAE no ambiente uterino, visto que pode ocorrer transmissão da CAE de matrizes portadoras do vírus para suas crias durante a prenhez ou no peri-parto. Assim, a separação das crias logo após o nascimento e o uso dos métodos de controle restringindo leite e colostro para as crias pode não ser $100 \%$ efetivos, o que explicaria a persistência do vírus nos rebanhos onde são seguidos rigorosos programas de controle da CAE (ANDRIOLI et al., 2006).

Segundo Santa Rosa (1996), o tempo necessário para eliminar a doença do rebanho depende da pressão que se estabelece no programa de controle empregado. Quando o rebanho já está praticamente limpo, mas ainda possui cabras soro positivas comprovadamente superiores, cujo material genético é realmente de grande importância, uma alternativa é a inclusão desses animais em um programa de transferência de embriões, desde que possam permanecer isolados do rebanho (RIBEIRO, 1997) já que a CAE não é transmitida pela transferência de embriões.

Segundo Franke (1998b), o criador de caprinos pode desempenhar um importante papel no controle da disseminação da CAE. Para isso, é necessário que ele incentive a sua associação a promover discussões sobre este tema, convidando pesquisadores da área e, juntos, elaborarem propostas de planos regionais de controle. Outra forma de colaboração dos caprinocultores seria a de exigirem o exame sorológico da CAE na inscrição em exposições, bem como nas transações de compra e venda de animais. Em hipótese alguma os animais positivos poderão ser vendidos a outros criadores. A saída de animais positivos de uma propriedade só poderá ser permitida quando estes se destinarem ao abate. O rebanho é considerado livre da doença quando apresentar pelo menos dois resultados consecutivos de sorologia negativa com intervalo mínimo de seis meses (SANTA ROSA, 1996). 


\subsection{BIOLOGIA MOLECULAR}

Estudos referentes à área de biologia molecular teve início em 1985 em que Chiu et al. comparou os genomas dos retrovírus da subfamília Lentivirus causadores da artrite encefallite caprina, anemia infecciosa eqüina e síndrome da imunodeficiência adquirida humana. Desde então se descobriu um campo fértil para diversas pesquisas relacionadas ao vírus da CAE. Algumas delas se dedicaram a padronização das técnicas biomoleculares com o intuito de auxiliar e fornecer como alternativa aos métodos de diagnóstico (REDDY et al., 1993; RIMSTAD et al., 1993; BARLOUGH et al., 1994; LEROUX et al., 1995; CHEBLOUNE et al., 1996; RUSSO et al., 1997) a detecção do agente em diferentes tipos de amostras e a investigação dos meios de transmissão do virus. Outras tiveram direcionamento ao estudo filogenético do genoma do vírus da CAE. Obteve-se muitas descobertas com relação à variedade existente no vírus permitindo a sua classificação em grupos e subgrupos, evidências tanto na queda da barreira de transmissão interespécies quanto na disseminação mundial do vírus por meio do comércio de animais.

No Brasil, Castro et al. (1999) sequenciaram os primeiros isolados de caprinos provenientes dos estados de Minas Gerais e Pernambuco. Um isolado de caprino seqüenciado mostrou-se mais próximo ao vírus Maedi Visna do que ao vírus da Artrite Encefalite Caprina sugerindo possível transmissão interespécies. Ravazzolo et al. (2001) foram responsáveis pela análise filogenética do primeiro lentivirus isolado de ovino proveniente do estado do Rio Grande do Sul. O estudo sugere como possível marcador a presença de uma deleção no gene gag no vírus do Maedi Visna para diferenciar a transmissão de lentivirus entre ovinos e caprinos.

Zanoni et al. (1998) apresentou uma classificação para os diferentes tipos virais seqüenciados de CAEV e MaediVisna existentes até então. Foi dividido em seis grupos nomeados em I, II, III, IV, V e VI. Os seis isolados puderam ser diferenciados porém sem uma clara separação entre as linhagens dos Lentivirus de Pequenos Ruminantes derivados de caprinos (Vírus da Artrite Encefalite Caprina) ou de ovinos (vírus do Maedi-Visna).

Porém a classificação sugerida por Zanoni et al. (1998) considerou sequencias curtas de isolados. Com isso, foi sugerido uma nova reclassificação por Shah et al. (2004) baseados em sequencias longas e de 104 isolados provenientes 
da Suíça e em seis sequencias disponíveis no banco de dados Genbank. O estudo propôs a divisão em quatro grandes grupos nomeados em $A, B, C$ e D com subdivisões em cada. O subgrupo B1 possui isolados provenientes da França, Brasil, Estados Unidos e Suíça, não existindo significativas diferenças entre elas o que sugeriu uma propagação do vírus por meio do comércio internacional de animais.

Recentes estudos de Lentivirus de Pequenos Ruminantes apontam para a uma nova direção. Glaria et al. (2009) mostraram a importância de uma possível correspondência entre genótipo e fenótipo e trouxeram evidências de controvérsia na área de pesquisa dentro dos Lentivirus de Pequenos Ruminantes. Mcelliott et al. (2010, não publicado ${ }^{1}$ ) estudam a associação do tropismo tecidual e a variação da sequencia promotora no vírus do Artrite Encefalite Caprina.

1

1. Comunicação verbal 


\section{MATERIAL E MÉTODOS}

\subsection{ANIMAIS}

Foram utilizadas durante o período, 185 amostras clínicas de caprinos de idade e raça variáveis, oriundos de regiões do Estado de São Paulo e provenientes do Serviço de Clínica de Bovinos e Pequenos Ruminantes da Faculdade de Medicina Veterinária e Zootecnia da Universidade de São Paulo.

Os animais primeiramente foram avaliados através do exame clínico geral segundo Rosenberger (1994) e os dados encontrados foram compilados em ficha clínica. Os animais suspeitos foram separados e foi realizada a sorologia através da imunodifusão em ágar gel. Foram colhidas as 185 amostras clínicas compreendendo amostras de leite, sangue total, liquido sinovial e sêmen dos animais que apresentaram sintomas ou soropositividade de órgãos (glândula mamária, pulmão e cérebro), se viessem a óbito, para a detecção do vírus por PCR e análise filogenética através do seqüenciamento. Os resultados do exame clínico e do seqüenciamento das amostras foram tabulados para realização da análise estatística.

\subsection{COLHEITA E PROCESSAMENTO DAS AMOSTRAS DE SANGUE}

Após a seleção, foram colhidas amostras de sangue através da punção da veia jugular externa, sem o garroteamento excessivo do vaso, utilizando-se o Sistema Vacutainer, em tubos de vidro siliconizados sem anticoagulante e com anticoagulante EDTA, provido de tampa de borracha e com vácuo suficiente para aspirar $10 \mathrm{ml}$ de sangue. No Laboratório de Pesquisa do Departamento de Clínica Médica da Faculdade de Medicina Veterinária da Universidade de São Paulo e no Laboratório de Raiva e Encefalites no Instituto Biológico, as amostras de sangue sem anticoagulante foram centrifugadas com força real de centrifugação igual a 
1000g, por 15 minutos, para a ocorrência de uma adequada sinerese do coágulo. A seguir, o soro sangüíneo foi separado por aspiração e as amostras de soro assim obtidas foram conservadas em "freezer" a menos $20^{\circ} \mathrm{C}$ até a realização das provas. As amostras de sangue com anticoagulante EDTA foram encaminhadas para o Laboratório de Virologia Molecular e Clínica no Instituto de Ciências Biomédicas USP sob supervisão do Prof. Dr. Edison Luiz Durigon para o processamento imediato e realização das técnicas de PCR, nested-PCR e seqüenciamento.

\subsection{PROVA DE SORODIAGNÓSTICO PARA O VÍRUS DA ARTRITE-ENCEFALITE CAPRINA}

A detecção de anticorpos séricos contra o vírus da artrite-encefalite caprina foi realizada pelo teste de imunodifusão em gel de ágar (IDGA), segundo Crawford e Adams (1981), utilizando o antígeno viral P28 (Kit para Diagnóstico de CAE, Biovetech, Brasil). A técnica consiste em possibilitar a conjugação de anticorpos séricos com o antígeno viral em agarose a 0,9\% em tampão fosfato, utilizando $30 \mu \mathrm{L}$ de soro/antígeno, com conseqüente precipitação do complexo constatada por leitura realizada 24 a 48 horas após, com luz indireta sobre fundo escuro, sendo considerada definitiva a última leitura.

\subsection{AMOSTRAS DE SÊMEN E LEITE}

As amostras de leite foram colhidas no momento da ordenha dos animais e acondicionadas em tubo estéril. A colheita do sêmen foi inicialmente realizada com a utilização de vagina artificial. Em animais que não aceitaram esse método de colheita, o procedimento utilizado foi por meio da técnica de eletroejaculação. As amostras foram encaminhadas para o Laboratório de Virologia Molecular e Clínica no Instituto de Ciências Biomédicas - USP sob supervisão do Prof. Dr. Edison Luiz Durigon para o processamento e realização das técnicas de PCR, nested-PCR e 
seqüenciamento, sendo mantidas sob refrigeração a menos $70^{\circ} \mathrm{C}$ até a realização das provas.

\subsection{EXTRAÇÃO DAS AMOSTRAS CLÍNICAS}

Os fragmentos dos referidos órgãos foram mantidos em freezer $-70^{\circ} \mathrm{C}$ até o momento da sua utilização. Foram pesados e macerados separadamente dois gramas das amostras de cérebro, glândula mamária e pulmão e realizada a suspensão a $20 \%$ com a utilização de PBS. As suspensões dos órgãos macerados foram mantidas $\mathrm{a}-20^{\circ} \mathrm{C}$ até sua extração.

Foi incubado $20 \mu \mathrm{L}$ de amostra por 30 minutos a $56^{\circ} \mathrm{C}$, em $150 \mu \mathrm{L}$ de TNE (Tris $\mathrm{HCl} 10 \mathrm{mM}$, EDTA $10 \mathrm{mM}$ e $\mathrm{NaCl} 10 \mathrm{mM}, \mathrm{pH} 8,0$ ) acrescidos de $20 \mu \mathrm{L}$ de SDS 10\% (Dodecil Sulfato de Sódio), 10 LL de pK (Proteinase K)

Para a realização das técnicas biomoleculares o DNA proviral de leite, líquido sinovial, sêmen e suspensão de órgãos macerados foi extraído pelo método Fenol/Clorofórmio/Álcool isoamil e constituiu na realização de três lavagens consecutivas com 200 $\mu \mathrm{L}$ de Fenol Buffer Saturado, $150 \mu \mathrm{L}$ de Fenol/Clorofórmio/Álcool Isoamil (25:24:10) e $100 \mu \mathrm{L}$ de Clorofórmio 100\% respectivamente, centrifugadas a 12.000 rpm por três minutos cada em temperatura entre $18^{\circ} \mathrm{C}$ e $22^{\circ} \mathrm{C}$. O material da extração $(40 \mu \mathrm{L})$ foi armazenado a $-20^{\circ} \mathrm{C}$, até ser utilizado na amplificação. O controle negativo foi feito com água DEPC enquanto que o controle positivo foi a amostra padrão CAEV Cork.

As amostras de sangue total com EDTA seguiram protocolo de extração de kit comercial GE Healthcare - illustra ${ }^{T M}$ blood genomicPrep Mini Spin (cód. 28-904264). Foi incubado $300 \mu \mathrm{L}$ da amostra de sangue total previamente homogeneizado com $20 \mu \mathrm{L}$ de proteinase $\mathrm{K}$ e $400 \mu \mathrm{L}$ de tampão de lise. A mistura foi homogeneizada três vezes por aproximadamente 20 segundos utilizando o vórtex com intervalo de 5 minutos cada. A mistura foi transferida para as colunas com filtros e centrifugada em $11000 \mathrm{~g}$ à $21^{\circ} \mathrm{C}$ por dois minutos descartando-se o filtrado. A seguir foi adicionado $500 \mu \mathrm{L}$ de tampão de lise e centrifugado novamente em 11000 $g$ à $21^{\circ} \mathrm{C}$ por dois minutos descartando-se o filtrado. Numa última lavagem foi adicionado novamente $500 \mu \mathrm{L}$ de tampão de lise e centrifugado em $11000 \mathrm{~g}$ à $21^{\circ} \mathrm{C}$ 
porém agora por 4 minutos. E finalmente foi adicionado $200 \mu \mathrm{L}$ de tampão de eleição aquecido à $70^{\circ} \mathrm{C}$ aguardando um minuto antes de centrifugar em $11000 \mathrm{~g}$ à $21^{\circ} \mathrm{C}$ por dois minutos. As amostras foram guardadas à $-20^{\circ} \mathrm{C}$.

\subsection{DIAGNÓSTICO MOLECULAR}

Foram utilizados primers gerados especificamente para um fragmento conservado do gene pol, empregando-se iniciadores degenerados situado entre as posições 2198 e 2650 (LEROUX et al., 1995) para amplificar fragmentos de 475pb (Tabela 7).

Tabela 7 - Oligonucleotídeos iniciadores usados na PCR para amplificação do gene pol

\begin{tabular}{|c|c|c|}
\hline Nome & Oligonucleotídeo iniciador - Seqüência (5’ $\left.\rightarrow 3^{\prime}\right)$ a & Posição \\
\hline P1 & DSAAGARAAATTARARGG & $2198-2215$ \\
\hline $\mathrm{P} 2$ & ATCATCCATRTATATBCCAAATTG & $2672-2650$ \\
\hline
\end{tabular}

Os cDNAs foram amplificados em um volume total de $50 \mu \mathrm{L}$ contendo uma mistura de reagentes (Storage Buffer: $20 \mathrm{mM}$ Tris- $\mathrm{HCl}$ ( $\mathrm{pH}$ 8.0), $0.1 \mathrm{mM}$ EDTA, $1 \mathrm{mM}$ DTT, estabilizadores, 50\% (v/v) glicerol; 10X PCR Buffer: 200 mM Tris-HCl (pH8.4), $500 \mathrm{mM} \mathrm{KCl} ; 50 \mathrm{mM} \mathrm{MgCl}$; $10 \mu \mathrm{M}$ cada primer senso e anti-senso; $10 \mathrm{mM}$ mistura de dNTP; $1 U$ Taq DNA Polymerase). Foi utilizada a enzima Platinum®Taq DNA Polymerase invitrogen (Cat. No. 10966-020). A amplificação foi feita inicialmente a $95^{\circ} \mathrm{C}$ por cinco minutos e 35 ciclos de $95^{\circ} \mathrm{C}$ por 45 segundos para a denaturação, seguido de $55^{\circ} \mathrm{C}$ por 45 segundos para o pareamento/anelamento dos primers a por fim a $72^{\circ} \mathrm{C}$ por 45 segundo para extensão das fitas de DNA terminando o ciclo com $72^{\circ} \mathrm{C}$ por oito minutos e a $4^{\circ} \mathrm{C}$ até a retirada das amostras. A detecção do produto amplificado foi determinada pela corrida eletroforética. Foram submetidos $10 \mu \mathrm{L}$ dos produtos das reações em eletroforese em gel de agarose a 1,5\%, em tampão TBE 
(Tris Borato 0,09M e EDTA 0,002M pH 8,0) corados com brometo de etídio (1 $\mu \mathrm{g} / \mathrm{mL}$ ). As amostras foram coradas, uma a uma, com $2 \mu \mathrm{L}$ de loading buffer antes de serem aplicadas no gel. Um marcador de peso molecular de $100 \mathrm{pb}$, o controle negativo e o controle positivo foram incluídos no gel. Após a corrida eletroforética desenvolvida a $80 \mathrm{~V}$, os géis foram observado em luz ultravioleta com o auxílio de transiluminador e o registro fotográfico foi efetuado no fotodocumentador $\left(\right.$ BIORAD $\left.^{\circledR}\right)$.

\subsection{ANÁLISE FILOGENÉTICA}

\subsubsection{Purificação do produto amplificado}

O fragmento obtido na PCR foi purificado, para remoção dos restos de reagentes utilizados na amplificação do DNA, seguindo o seguinte protocolo. Foi acrescido $10 \mu \mathrm{L}$ de água DNAse/RNAse free em $40 \mu \mathrm{L}$ do produto de reação de PCR completando um volume de $50 \mu \mathrm{L}$. Foi adicionado $10 \%$ do volume total da reação, de acetato (v/v). Em seguida foram acrescentadas duas vezes o volume total com etanol $100 \%$, ou seja, se o volume total é de $55 \mu \mathrm{L}$, o volume acrescido de etanol será de $110 \mu \mathrm{L}$. Os tubos foram colocados no "freezer" a menos $20^{\circ} \mathrm{C}$ por um período de três horas, sendo centrifugados por 30 minutos a $14.000 \mathrm{rpm}$ a $4^{\circ} \mathrm{C}$. O sobrenadante foi descartado, invertendo-se o tubo sobre papel absorvente. Logo em seguida foram acrescidos $150 \mu \mathrm{L}$ de etanol $75 \%$ e centrifugados por 10 minutos a $14.000 \mathrm{rpm}$ a $4^{\circ} \mathrm{C}$. Então o sobrenadante foi novamente descartado invertendo-se o tubo em papel absorvente. Os tubos foram colocados no speed-vacuum a $60^{\circ} \mathrm{C}$ por 20 minutos e os pellets foram ressuspendidos em $50 \mu \mathrm{L}$ de água DNAse RNAse free. Os tubos contendo DNA purificado foram armazenados em "freezer" a menos $20^{\circ} \mathrm{C}$ até o uso na reação de sequenciamento.

Para o estudo filogenético, o DNA purificado foi seqüenciado para a região de interesse, parte do gene pol das amostras, utilizando o Kit de sequenciamento 
Dye Terminator Cycle Sequencing ABI PRISM ${ }^{\circledR} 3100$ Genetic Analyser (APPLIED Biosystems).

\subsubsection{Reação de seqüenciamento}

O volume total da reação de sequenciamento foi de $10 \mu \mathrm{L}$, contendo $2 \mu \mathrm{L}$ de Big Dye Terminator (APPLIED Biosystems), $2 \mu \mathrm{L}$ de Save Money [5M] (APPLIED Biosystems), $1 \mu \mathrm{L}$ de oligonucleotídeo (primer) [10pmol], $2 \mu \mathrm{L}$ de DNA (200-300ng) e $3 \mu \mathrm{L}$ de água livre de DNAse e RNAse. A quantidade de DNA variou de 2 a $3 \mu \mathrm{L}$, dependendo da intensidade da banda no gel e também da quantidade de DNA, pois isto acarretou variação na quantidade de água. Para cada reação, utilizou-se um oligonucleotídeo, ou seja, foi feita uma reação para o oligonucleotídeo no sentido 5' - 3' (senso) e uma para a reação para o oligonucleotídeo anti-sentido 3' - 5' (antisenso). Os oligonucleotídeos utilizados são: Primer sense (PN1) 5' GGA AAD GCA CCY CCA CAT TG 3' e Primer antisense (PN2) 3' CAT GGT TCC RAY ATT ATT AGG 5'. Ambos os oligonucleotídeos foram desenhados pelo laboratório de Virologia do Instituto de Ciências Biomédicas da USP.

A amplificação foi desenvolvida em termociclador (Mastercycler ep gradient -Eppendorf). As amostras foram, primeiramente, denaturadas a $96^{\circ} \mathrm{C}$ por 1 minuto e submetidas a 30 ciclos de amplificação, sendo cada ciclo composto de três temperaturas: denaturação das amostras a $96^{\circ} \mathrm{C}\left(15\right.$ segundos), anelamento a $50^{\circ} \mathrm{C}$ (15 segundos) e extensão a $60^{\circ} \mathrm{C}$ (4 minutos). Após o término o termociclador, a temperatura se manterá a $4^{\circ} \mathrm{C}$ até o processamento das amostras amplificadas. Para cada ciclo utilizou-se uma variação de $1^{\circ} \mathrm{C}$ por segundo de rampa. 


\subsubsection{Precipitação da Reação de seqüenciamento}

Após a reação de sequenciamento, as amostras foram precipitadas utilizando isopropanol $100 \%$ e $75 \%$ (MERCK).

À reação de sequenciamento acrescentou-se $30 \mu \mathrm{L}$ de água ultra-pura e 60 $\mu \mathrm{L}$ de isopropanol (MERCK). Os tubos foram deixados em temperatura ambiente por 15 minutos sob o abrigo de luz, então foram deixados dentro da centrifuga (5810R Eppendorf) fechada. Em seguida, os mesmos foram centrifugados por 30 minutos a 14000 rpm em temperatura ambiente. Após a centrifugação, descartaremos o sobrenadante invertendo os tubos sob papel absorvente, e acrescentaremos $150 \mu \mathrm{L}$ de isopropanol $75 \%$ em cada amostra, misturaremos com o auxílio de um vórtex e depois os centrifugaremos mais uma vez por 10 minutos a 14000 rpm. Descartaremos o sobrenadante invertendo os tubos sob papel absorvente, secaremos os tubos em um concentrador com uma bomba de membrana de PTFE resistente a produtos químicos (5301-Eppendorf), a $60^{\circ} \mathrm{C}$ por 20 minutos ou em temperatura ambiente protegido da luz. Ressuspenderemos o botão (pellet) em 10 $\mu \mathrm{L}$ de formamida $\mathrm{HI}$ DI (APPLIED Biosystems) no próprio tubo, misturaremos em vórtex e em seguida passaremo-os para uma placa de 96 orifícios. Após termos aplicado todas as amostras na placa, montamos uma planilha, que já vem pronta com o programa do seqüenciador, que possui o desenho da placa, identificando o orifício em que cada uma foi depositada. Posteriormente, as amostras foram denaturadas a $93^{\circ} \mathrm{C}$ por 5 minutos e em seguida sofreram um choque térmico de $4^{\circ} \mathrm{C}$, em gelo por um minuto. Colocaremos a placa no seqüenciador $A B I P R I S M$ 3100 (APPLIED Biosystems), seguindo as instruções do fabricante.

\subsection{ANÁLISE E ALINHAMENTO DAS SEQÜÊNCIAS}

As sequências foram editadas e alinhadas com o programa BioEdit Sequence Alignment Editor. As seqüências de nucleotídeos serão analisadas com o programa Sequence Navigator versão 1.0 (Applied Biosystems, Inc., EUA) para Power Macintosh, alinhadas utilizando o programa Meg Align 4.05 - DNAstar e 
observar sua variabilidade com o programa Meg AlignTM v. 1.02: Molecular Evolutionary Genetics Analysis. Averiguaremos se a variabilidade genética encontrada no vírus possui predileção ao sinal clínico apresentado.

Os números de acesso do Genbank para as seqüências retiradas da literatura utilizadas para o alinhamento são VVU35679.1, VVU35680.1, VVU35676.1, (LEROUX et al., 1995); L78448.1, (STORSET; RIMSTAD²); AY900630.1 (não publicado $^{3}$ ); M33677.1, (SALTARELLI et al., 1990); M31646.1-SA-OMVV (QUERAT et al., 1990); AJ305050.1, AJ305051, AJ305052, AJ305053 (RAVAZZOLO et al., 2001); AF108048.1, AF108049.1, AF108051.1, AF108053.1, AF108056.1, AF108059.1 (CASTRO et al., 1999); AY454178.1, AY454197.1, AY454218.1, AY454175.1, AY454190.1, AY454210.1, AY454161.1, AY454231.1, AY454189.1, AY454208.1 (SHAH et al., 2004); FJ195346.1 (GLARIA et al., 2009); DQ013218.1 DQ013215.1, DQ013231.1, DQ013225.1, DQ013236.1, DQ013242.1 (PISONI et al., 2005); AY101611.1 (HOTZEL; CHEEVERS ${ }^{4}$ ); K03327.1 (CHIU et al., 1985); AF015182.1 (VALAS et al., 1997); AF322109.1 (retirado do GenBANK); M10608.1 (SONIGO et al., 1985); S51392.1 (SARGAN et al., 1991); AM419950.2 (LAAMANEN et al., 2007).

Para a reconstrução filogenética dos isolados de CAEV, foi utilizado o método de distância com o algoritmo Neighbor-Joining e modelo evolutivo Maximum Composite Likelihood (MCL), para nt, e modelo evolutivo de Poisson para aa, com 1000 repetições de bootstrap. com o programa Mega 4 (TAMURA et al., 2007).

\footnotetext{
2 - Comunicação verbal

3 - Comunicação verbal

${ }^{4}$ Comunicação verbal
} 


\section{RESULTADOS}

\subsection{CASUÍSTICA}

O estudo foi baseado nos resultados de quatorze isolados seqüenciados de amostras clínicas diversas provenientes de oito animais. A relação de todos os isolados seqüenciados de acordo com cada animal é indicada na tabela abaixo (Tabela 8).

Tabela 8 - Relação de todos os isolados seqüenciados, tipo de amostra clínica e animais

\begin{tabular}{ccc}
\hline Animal & Amostra clínica & $\begin{array}{c}\text { Nomenclatura do } \\
\text { isolado sequenciado }\end{array}$ \\
\hline Cabra 17 & Líquido sinovial & C7LS \\
\cline { 2 - 3 } Drica & Pulmão & C8P \\
\cline { 2 - 3 } & SNC & C9C \\
\cline { 2 - 3 } & Glândula mamária & C10GM \\
\cline { 2 - 3 } Sem Identificação & Leite gland. direita & $\mathrm{C} 16 \mathrm{~L}$ \\
\cline { 2 - 3 } & Leite gland. esquerda & $\mathrm{C} 17 \mathrm{~L}$ \\
\hline Liza & Leite gland. esquerda & $\mathrm{C} 29 \mathrm{~L}$ \\
\hline Astúria & Leite gland. esquerda & $\mathrm{C} 31 \mathrm{~L}$ \\
\hline Cabra 103 & Glândula mamária & $\mathrm{C} 103 \mathrm{GM}$ \\
\hline Cabra 107 & SNC & $\mathrm{C} 107 \mathrm{C}$ \\
\hline \multirow{2}{*}{$5 \mathrm{BC}$} & Leite gland. esquerda & $\mathrm{C} 131 \mathrm{~L}$ \\
\cline { 2 - 3 } & Leite gland. direita & $\mathrm{C} 132 \mathrm{~L}$ \\
\hline \multirow{2}{*}{ 2s7 } & Leite & $\mathrm{C} 137 \mathrm{~L}$ \\
\hline \multirow{2}{*}{ Aviana } & Leite gland. direita & $\mathrm{C} 144 \mathrm{~L}$ \\
\hline Marcelo & Sangue total & $\mathrm{C} 148 \mathrm{ST}$ \\
\hline & Líquido sinovial & $\mathrm{C} 177 \mathrm{LS}$ \\
\hline
\end{tabular}

\subsection{EXAME CLÍNICO DOS ANIMAIS}

A cabra 17 proveniente do Hovet-USP apresentava quadro de artrite na articulação do carpo com presença de aumento de volume e mobilidade comprometida.

A cabra Drica também proveniente do Hovet-USP encontrava-se numa evolução muito crônica da enfermidade apresentando emagrecimento progressivo, articulações do carpo calcificadas com pouca mobilidade e pneumonia crônica. 
Ao exame clínico da cabra Liza, na glândula mamária direita houve a presença à palpação um endurecimento difuso na intensidade de (++) e um nódulo. A glândula esquerda apresentava à palpação um endurecimento difuso na intensidade de $(++)$ e a presença de dois nódulos na região anterior da glândula. Ao teste de CMT (California Mastitis Test) ambas as glândulas apresentaram resultados negativos. O animal era proveniente de uma propriedade localizada no município de Ibiúna-SP.

A cabra Astúria, da mesma propriedade do animal anterior, apresentava à palpação de ambas as glândulas mamárias endurecimento difuso com intensidade de $(++)$ e resultado de CMT também negativos.

O animal 5BC era proveniente de uma propriedade localizada no município de Itu-SP e apresentava à palpação endurecimento difuso com intensidade de (++) em ambas as glândulas mamárias.

A cabra 2s7 era proveniente de uma propriedade localizada no município de Tatuí-SP e apresentava à palpação endurecimento difuso com intensidade de $(+)$ em ambas as glândulas mamárias. O proprietário relatou histórico de abortamento dois meses antes da ocasião da visita.

A cabra Aviana era proveniente do Hovet-USP e apresentava emagrecimento progressivo, agalaxia na glândula esquerda, endurecimento difuso com intensidade (++). Apresentava artrite em articulação do tarso esquerdo, do carpo direito e da articulação atlanto-occipital. O resultado do teste de CMT da glândula direita foi (+).

O bode Marcelo, animal também proveniente do Hovet-USP, apresentava aumento de volume em articulação de carpos e mobilidade diminuída das articulações.

\subsection{DIAGNÓSTICO MOLECULAR}

De 185 amostras totais submetidas à reação de PCR e nested-PCR 39 amostras produziram banda positiva $(21,08 \%)$, como demonstrado na figura 14 , sendo que 28 das positivas compreenderam quinze amostras de leite, sete amostras 
de sêmen, duas amostras de SNC, duas amostras de líquido sinovial, uma amostra de glândula mamária, uma amostra de pulmão.

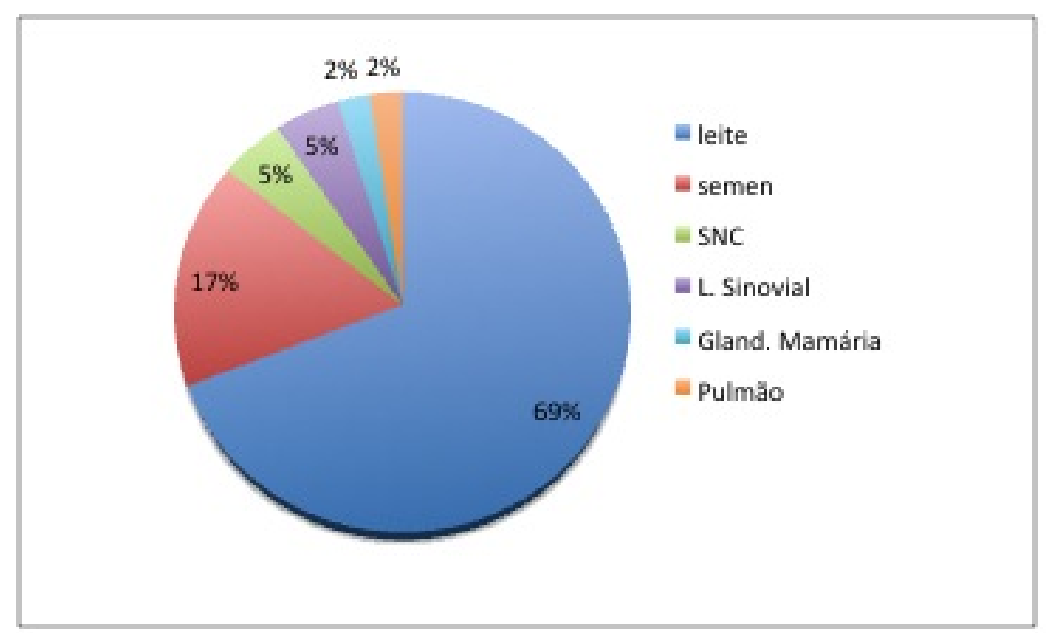

Figura 14 - A figura mostra a ocorrência de CAEV em diferentes tipos de liquido corporais coletados dos caprinos

\subsection{SEQUENCIAMENTO DO CAEV}

Foi submetido um total de 16 isolados a reação de seqüenciamento. As amostras foram as seguintes: C7LS, C80, C9C, C10GM, C16L, C17L, C29L, C31L, C103GM, C107C, C131L, C132L, C137L, C144L, C148ST e C177LS.

\subsection{ESTUDO FILOGENÉTICO}

O estudo filogenético realizado utilizou apenas 14 dos 16 isolados. Foram utilizadas sequências disponíveis no Genbank para o estudo. As tabelas abaixo mostram as identidades entre os isolados do estudo e os isolados disponíveis no Genbank.

As seqüências brasileiras e as seqüências padrão obtidas do genBank foram analisadas empregando-se a metodologia de Máxima Verossimilhança, modelo evolutivo F84. Foi realizada um busca heurística, com algoritmo de bissecção de árvore TBR (tree bisection reconnection). A topologia da árvore proposta para as amostras do grupo $\mathrm{A}$, B e $\mathrm{C}$, pelo método de $\mathrm{MV}$, utilizando-se o algoritmo TBR está 
representada na figura 15, foram verificadas amostras idênticas entre si e amostras diferentes circulando no Brasil.

Foi verificada uma variabilidade genética do subgrupo B1 o qual foi o genótipo predominante. O genótipo de CAEV do tipo B demonstrou um padrão de diversidade genética de no Maximo 14\%, quando comparadas entre si.

O genótipo $A$ do CAEV não foram encontrado em nossas amostras e se concentrou em um clado separado, evidenciando uma homogeinidade genética das mesmas.

O grupo C quando comparado entre si, obtiveram um padrão de distancia de $11 \%$, entretanto duas amostras de nosso estudo (C31Lastutia esquerdo e C137 L2S-1) demonstram ser um clado muito próximo do tipo $C$ embora com divergências próprias. 


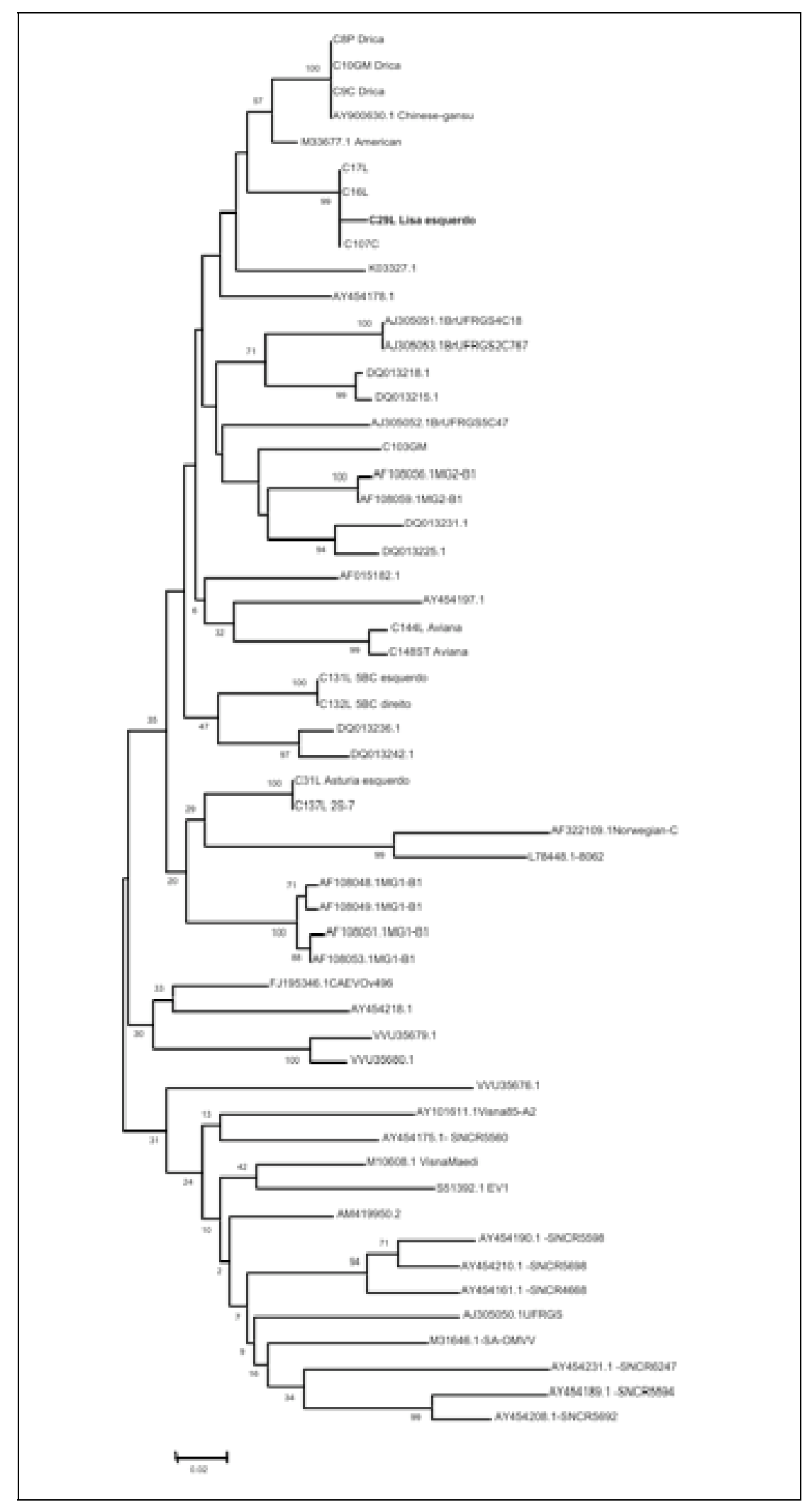

mundo

Figura 15 - Árvore filogenética dos seqüenciados de CAEV no Brasil e no 
A tabela 9 apresenta a comparação entre as identidades dos grupos: Marjorie entre si, dos grupos internacionais, dos grupos brasileiros, de Marjorie com os grupos brasileiros e de Marjorie com os grupos interacionais. As identidades de cada seqüenciado presentes no GenBank estão expostas nos anexos.

Tabela 9 - Nivel de identidade do grupo interno Marjorie ( Ids B1 MArjorie), onde compara-se o seqüenciado por Marjorie com o dela mesma; Identidade do grupo seqüenciado B do Gen Bank (Ids B-GB); Identidade do grupo B brasileiro do Gen Bank (Ids B-Br-GB); Identidade do grupo seqüenciado por Marjorie versus o grupo B do Gen Bank (Ids B1 Marjorie Vs. B-GB); identidade do grupo seqüenciado por Marjorie versus o grupo B brasileiro do Gen Bank (Ids B1 Marjorie Vs. B-Br-GB)

\begin{tabular}{lr}
\hline Comparações & Nivel de Identidade \\
\hline Ids B1 Marjorie & 0,90108 \\
Ids B-GB & 0,87556 \\
Ids B-Br-GB & 0,87851 \\
Ids B1 Marjorie Vs. B-GB & 0,87825 \\
Ids B1 Marjorie Vs. B-Br-GB & 0,86952 \\
\hline
\end{tabular}




\section{DISCUSSÃo}

A genotipagem através do seqüenciamento parcial do gene $\mathrm{POL}$ das amostras de CAEV isoladas neste estudo, mostrou a presença do grupo $B$ circulando nas diferentes amostras estudadas e com sintomas clínicos distintos. Nossa Análise também demonstra claramente uma dominância do genótipo B1.

A analise filogenética das cepas de CAEV revelou uma epidemiologia complexa e dinâmica deste vírus que pode diferir dentro de uma mesma comunidade e ser idênticas entre diferentes localidades, ao exemplo da cepas que foram identificadas no Brasil e é geneticamente similar a cepas isoladas na China. A análise filogenética obtida do sequenciamento do gene Pol de CAEV isolados da C31L Asturia e C137L25-1 demonstraram pequena variabilidade do gene agrupando-as em clados próximos, ao do tipo $\mathrm{C}$, porém com significativa divergencia dos outros grupos do genótipo B1 isolados em diferentes regiões brasileiras.

Em nosso estudo, analisando a arvore (Figura 15), fica evidente no grupo B a distribuição de do subgrupos $B 1$ onde os isolados brasileiros se distribuem de maneira bastante uniforme. Já em relação ao grupo A, não foram identificadas amostras brasileiras circulando nos animais estudos. Estudos futuros, pelo seqüenciamento do gene pol serão imprescindíveis para uma análise mais acurada da distribuição dos diferentes genótipos dos isolados brasileiros.

Nossos dados gerados durante esse estudo, certamente trará uma contribuição para melhor definir a epidemiologia do CAEV, como a distribuição por diferentes patologias, bem como a diversidade genética dos isolados de CAEV circulantes em nosso meio. 


\section{CONCLUSÕES}

- Há uma predominância do grupo B1 em todas as amostras já seqüenciadas no mundo;

- Neste estudo também houve predominância do grupo B;

- Neste estudo duas amostras foram classificadas no grupo C;

- Nesta pesquisa, assim como nas amostras brasileiras já sequenciadas não há presença de amostras do grupo A. 


\section{REFERÊNCIAS}

ABREU, S. R. O., CASTRO, R. S., NASCIMENTO, S. A., SOUZA, M. G. Produção de antígeno nucleoprotéico do vírus da artrite-encefalite caprina e comparação com o do vírus maedi-visna para utilização em teste de imunodifusão em agar gel. Pesq. Vet. Bras., 1998.

ADAMS, D. S.; CRAWFORD, T. B.; BANKS, K. L.; McGUIRE, T. C.; PERRYMAN, L. E. Immune responses of goats persistently infected with caprine arthritis-encephalitis virus. Infect. Immun., v. 28, n. 2, p. 421-427, 1980.

ADAMS, D. S., GORHAM, J. R. The gp 135 of caprine arthritis-encephalitis virus affords greater sensitivity than the p 28 in immunodifusion serology. Res. Vet. Sci., v. 40, p. 157-160, 1986.

ADAMS, D. S., KLEVJER-ANDERSON, P., CARLSON, B. S., McGUIRE, T. C. Transmission and control of caprine arthritis-encephalitis virus. Am. J. Vet. Res., V. 44, p. 1670-1675, 1983.

ALFONSO CLAVIJO, THORSEN, J. Bacterial expression of caprine arthritisencephalitis virus gag and env proteins and their use in enzyme-linked immunosorbent assay. Am. J. Vet. Res., v. 56, p. 841-848, 1995.

ALI, A. O. Caprine arthritis-encephalitis related changes in the uterus of a goat. Vet. Rec. ,v. 121, p. 131-132, 1987.

ANDRIOLI, A., GOUVEIA, A. M. G., MARTINS, A. S., PINHEIRO, R. R., SANTOS, D. $O$. Fatores de risco na transmissão do lentivírus caprino pelo sêmen. Pesq. Agropec. Bras., v. 41, n. 8, p. 1313-1319, 2006.

ARCHAMBAULT, D., EAST, N., PERK, K., DAHLBERG, J.E. Development of an enzime-linked Immunosorbent assay for caprine arthritis-encephalitis virus. J. Clinical Microbiol., v. 26, p. 971-975, 1988.

ASSIS, A. P. M. V.; GOUVEIA, A. M. G. Evidências sorológicas de Lentivirus (Maedi/Visna/Artrite-Encefalite Caprina) em rebanhos nos Estados de MG., RJ., BA e CE. In: CONGRESSO BRASILEIRO DE MEDICINA VETERINÁRIA, 23, 1994, Olinda, Pernambuco. Anais. p. 104.

BARLOUGH, J., EAST, N., ROWE, J. D., VAN HOOSEAR, K., DEROCK, E., BIGORNIA, L., RIMSTAD, E., VAN HOOSEAR, K. Double-nested polymerase chain reaction for detection of caprine arthritis-encephalitis virus proviral DNA in blood, milk, and tissues of infected goats. J. Virol. Methods, v. 50, p. 101-114, 1994.

BEER, J. Doenças infecciosas em animais domésticos. São Paulo: Roca, 1998, $380 \mathrm{p}$.

BERTONI, G, ZAHNO, M. L., ZANONI, R, VOGT, H. R., PETERHANS, E., RUFF, G., CHEEVERS, W. P., SONIGO, P., PANCINO, G. Antibody reactivity to the immunodominant epitopes of the caprine arthritis-encephalitis virus gp38 
transmembrane protein associates with the development of arthritis. J. Virol., v. 68, p. 7139-7147, 1994.

BIRGEL, E. H. Artrite-encefalite dos Caprinos. São Paulo, 2000. 38 p. Apostila do $6^{\circ}$ Encontro nacional para o Desenvolvimento da Espécie Caprina.

BIRGEL JUNIOR, E. H.; CESTARI, V.; SAMPAIO, R. M.; BIRGEL, D. B.; RAIMONDO, R. F.; BRANDESPIN, F. B.; BIRGEL, E. H. Influência da infecção pelo vírus da artrite encefalite caprina nas características físico-químicas, celulares e microbiológicas do leite de caprinos. In: CONGRESSO BRASILEIRO DE BUIATRIA, 5., 2005, Búzios - RJ. Anais... Rio de Janeiro: Editora, 2005.

BLOOD, D. C.; RADOSTITIS, O. M. Clínica veterinária São Paulo, Guanabara Koogan, 1991. p. 783-784.

BOHLAND, E. Artrite Encefalite Caprina: avaliação dos aspectos produtivos e reprodutivos de animais infectados e não infectados. 1998. 95 f. Dissertação (Mestrado em Clínica Veterinária). ) - Faculdade de Medicina Veterinária e Zootecnia, Universidade de São Paulo, São Paulo, 1998.

BRODIE, S., PEARSON, L., ZINK, M., BICKLE, H., ANDERSON, B., MARCOM, K., DEMARTINI, J. Ovine lentivirus expression and disease. Virus replication, but not entry, is restricted to macrophages of specific tissues. Am. J. Pathol., v. 146, p. 250263, 1995.

CALLADO, A. K. C., CASTRO, R. S., TEIXEIRA, M. F. S. Lentivírus de pequenos ruminantes (CAEV e Maedi-Visna): revisão e perspectivas. Pesq. Vet. Bras. vol. 21, n. 3, Rio de Janeiro, 2001

CASTRO, R. S. Lentivírus de pequenos ruminantes: ensaios imunoenzimáticos, perfil sorológico e inferências filogenéticas. 1998128 f. Dissertação (Doutorado em Ciência Animal) - Escola de Veterinária, Universidade Federal de Minas Gerais, Belo Horizonte, Belo Horizonte, 1998.

CASTRO, R. S.; LEITE, R. C.; RESENDE, M.; MARTINS, A.; GOUVEIA, A. M. G. Isolamento e identificação pela imunofluorescência direta e reação em cadeia de polimerase do vírus da artrite-encefalite caprina. Arquivo Brasileiro de Medicina Veterinária e Zootecnia, v. 51, n. 3, p. 235-240, 1999.

CHEBLOUNE, Y., KARR, B., SHEFFER, D., LEUNG, K., NARAYAN, O. Variation in lentiviral gene expression in monocyte-derived macrophages from naturally infected sheep. J. Gen. Virol., v. 77, p. 2037-2051, 1996.

CHEEVERS, W. P., KNOWLES, D. P., MCGUIRE, T. C., CUNNINGHAM, D. R., ADAMS, D. S., GORHAM, J. R. Chronic disease in goats orally infected with two isolates of the caprine arthritis encephalitis lentivirus. Lab. Inv., v. 58, p. 510-517, 1988.

CHEEVERS, W.; McGUIRE, T.; NORTON, L. K.. Failure of neutralizing to regulate CAE lentivirus expression in vivo. Virology. V. 196, p. 835-839, 1993. 
CHIU, I., YANIV, A., DAHLBERG, J. E., GAZIT, A., SKUNTZ, S., TRONICK, S. R., AARONSON, S. A. Nucleotide sequence evidence for relationship of AIDS retrovirus to lentiviruses. Nature, v. 317, 1985.

CLEMENTS, J. E., PAYNE, S. Molecular basis of the pathobiology of lentiviruses. Vir. Res., v. 32, p. 97-109, 1994.

COFFIN, J. M. Retroviridae: The viruses and their replication. In: FIELDS, B. N.; KNIPE, D. M.; HOWLEY, P. M. Fundamental virology. Philadelphia: Lippincott Raven, 1996, p. 763-843.

CONCHA-BERMEJILLO, A. de la; MAGNUS-CORRAL, S.; BRODIE, S. J.; DeMARTINI, J. C. Venereal shedding of ovine lentivirus in infected rams. American Journal of Veterinary Research, v. 57, p. 684-688, 1996.

CONCHA-BERMEJILLO, A. de la. Maedi-visna and ovine progressive pneumonia. Vet. Clin. North Am.: Food Anim. Pract., v. 13, p. 12-33, 1997.

CONSTABlE, P. D., MEIER, W. A., FOLEY, G. L., MORIN, D.,CUTLIP, R. C., ZACHARY, J. F. Visna-like disease in a ram with chronic demyelinating encephalitis. J. Am. Vet. Med. Assoc., v. 208, p.117-120, 1996.

CORK, L. C.; HADLOW, W. J.; CRAWFORD, T. B.; GORHAM, J. R.; PIPER, R. C. Infectious leukoencephalomyelitis of young goats. Journal of Infectious Diseases, v. 129, n. 2, p. 134-141, 1974.

CRAWFORD, T. B.; ADAMS, D. S.; CHEEVERS, W. P.; CORK, L. C. Chronic arthritis in goats caused by a retrovirus. Science, v. 207, n. 29, p. 997-999, 1980.

CRAWFORD, T. B., ADAMS, D. S. Caprine arthritis-encephalitis: clinical features and presence of antibody in selected populations. J. Am. Vet. Med. Assoc., v. 178, p. 713-719, 1981.

CUNHA, R. G.; NASCIMENTO, M. D. Ocorrência de anticorpos para o vírus da artrite-encefalite caprina em soros de caprinos do Estado do Rio de Janeiro. Revista Brasileira de Medicina Veterinária, v. 17, n. 2, p. 72-75, 1995.

CUTLIP, R. C., LEHMKUHL, D., SCHMERR, M. J. F., BROGDEN, K. A. Ovine progressive pneumonia (maedi-visna) in sheep. Vet. Microbiol., v.17, p. 237-250, 1988.

D'ANGELINO, J. L.; GARCIA, M.; BASTOS, P. S.; MOURÃO, M. A. F.; BOHLAND, E. Ocorrência da artrite encefalite caprina no Estado de São Paulo - Brasil.

Arquivos da Escola de Medicina Veterinária da Universidade Federal da Bahia, v. 16, n. 1, p. 60-66, 1993.

DeMARTINI, J. C.; BROODIE, S. J.; CONCHA, A. de la; ELLIS, J. A. Pathogenesis of lynphoid interstitial pneumonia in natural and experimental caprine lentivirus infection. Clin. Infection Disease. v. 17: p. 236-242, 1993. 
DOLF, G., RUFF, G. A DNA fingerprinting band associated with the susceptibility to CAE virus-induced arthritis in goats. Br. Vet. J., v.150, p.349-353, 1994.

EAST, N. E.; ROWE, J. D.; DAHLBERG, J. E.; THEILEN, G. H. \& PEDERSEN, N. C. Modes of transmission of capine arthritis-encephalitis virus infection. Small Rumin., n.10, p.251-262, 1993.

EAST, N. E.; ROWE, J. D.; MADEWELL, B. R.; FLOYD, K. Serologic prevalence of caprine artrhitis-encephalitis virus in California goat dairies. J. Am. Vet. Med. Ass., v. 190, p. 182-186, 1987.

EAST, N. E. Caprine arthritis encephalitis. In: SMITH, B. P. (Ed.). Large animal internal medicine. St. Louis: Mosby, 1996. p.1147-1148.

ELLIS, T. M.; CARMAN, H.; ROBINSON, W. F.; WILCOX, G. E. The effect of colostrum-derived antibody on neonatal transmission of caprine arthritis-encephalitis virus infection. Australian Veterinary Journal, v. 63, n. 8, p. 242-245, 1986.

ELLIS, J. A., RUSSEL, H.I., DU, C.W. Effect of selected cytokines on the replication of Corynebacterium pseudotuberculosis and ovine lentivirus in pulmonary macrophages. Vet. Immunol. Immunopathol., v. 40, p. 31-47, 1994.

FERNANDES, M. A. Artrite encefalite caprina - Contribuição para o estudo epidemiológico em rebanhos leiteiros criados no Estado de São Paulo. 1997. 83 f. Dissertação (Mestrado em Clínica Veterinária) - Faculdade de Medicina Veterinária e Zootecnia, Universidade de São Paulo, São Paulo, 1997.

FITERMAN, I. R. Constatação do complexo artrite-encefalite em um plantel de caprinos no Estado da Bahia. In: CONGRESSO BRASILEIRO DE MEDICINA VETERINÁRIA. 21., 1988, Salvador. Anais... Salvador: Sociedade Brasileira de Medicina Veterinária, 1988. p. 33.

FRANKE, C. R. Uma virose ameaça o rebanho nacional: artrite encefalite caprina (CAE). Bahia Agrícola. v. 2, n. 3, p. 89-92, 1998.

FRANKE, C. R. Controle sanitario da artrite-encefalite caprina. Salvador: EDUFBA, 1998b. 70 p.

FRANCKI, R. I. B., FAUQUET, C. M., KNUDSON, D. L., BROWN, F. M. Classification and nomenclature of viruses. Archives of Virology, p. 450, 1991, Supplementum 2.

GARCIA, M. Artrite encefalite caprina: uma nova doença no Brasil. A hora veterinária. São Paulo, v.13, n. 76, p. 57-59, 1993.

GLARIA, I., REINA, R., CRESPO, H., DE ANDRÉS, X., RAMÍREZ, H., BIESCAS, E., PÉREZ, M. M., BADIOLA, J., LUJÁN, L., AMORENA, B., DE ANDRÉS, D.

Phylogenetic analysis of SRLV sequences from an arthritic sheep outbreak 
demonstrates the introduction of CAEV-like viruses among Spanish sheep. Vet. Microbiol., v. 138, n. 1-2, p. 156-162, 2009.

GONZALEZ, L.; GELABERT, J. L.; MARCO, J. C. SAEZ-de-OKARIZ, C. Caprine arthritis encephalitis in the Basque country, Spain. Vet. Rec. v.120, p. 102-109, 1987.

GREGORY, L.; ANGELINI, M.; RIZZO, H.; HASEGAWA, M. Y.; RODRIGES, J. N. M.; DURIGON, E. L.; MEIRA JUNIOR, E. B. S.; CASTRO, R.S . Detecção por nested PCR de CAEV no sêmen de reprodutores caprinos no estado de São Paulo, Brasil. In: CONGRESSO BRASILEIRO DE REPRODUÇÃO ANIMAL, 17., 2007, Curitiba. Anais... Belo Horizonte, 2007.

GREGORY, L.; SILVA, L. C. L. C. ; ANGELINI, M. ; LARA, M. C. C. S. H. ; FRANCHINI, M L ; RIZZO, H.; CARDOSO, M. V.; BENESI, F. J. ; CASTRO, R. S. Avaliação clínica de caprinos acometidos por artrite. Diferencial entre artrite viral (CAE) e bacteriana (Mycoplasma spp.) em dois casos atendidos no hospital veterinário da FMVZ-USP. Arq.do Inst. Biol., São Paulo - SP, v. 73, n. 2, p. 247249, 2006.

GUEDES, M. I. M. C.; SOUZA, J. C. A.; GOUVEIA, A. M. G. Infecção experimental em cabritos pelo vírus da artrite encefalite. Arquivo Brasileiro de Medicina Veterinária e Zootecnia. Belo Horizonte, v. 53 n. 1, 2001

HECKERT, R. A.; McNAB, W. B.; RICHARDSON, S. M.; BRISCOE, M. R. Evaluation of an Enzyme-linked Immunosorbent Assay for the detection of antibodies to Caprine Arthritis-Encephalitis Virus in goat serum. Can. J. Vet. Res., v. 56, n. 3, p. 237-241, 1992.

HOUWERS, D. J., GIELKENS, A. L. J.; JAN SCHAAKE, Jr. J. An indirect enzimelinked immunosorbent assay (ELISA) for the detection of antibodies to MAEDI-VISNA virus. Vet. Microbiol., v. 7, p. 209-219, 1982.

HOUWERS, D. J.; SCHAAKE Jr. J. An improved ELISA for detection of antibodies to ovine and caprine lentiviruses, employing monoclonal antibodies in one-step assay. J. Immunol. Methods, v. 98, p. 151-154, 1987.

HOUWERS, D. J., VAN DER MOLEN, E. J. A five-year serological study of natural transmission of maedi-visna virus in a flock of sheep, completed with post mortem investigation. J. Vet. Med. B., v.34, p.421-431, 1987

HUSSO, L. D.; NARAYAN, O.; HART, W. G. Sialic acids on the surface of caprine arthritis-encephalitis virus define the biological properties of the virus. J Virol., v. 62, p. 1974-1980, 1988.

INSTITUTO BRASILEIRO DE GEOGRAFIA E ESTATÍSTICA - IBGE. Censo agropecuário. Disponível em:

http://www.sidra.ibge.gov.br/bda/tabela/listabl.asp?c=73\&z=t\&o=21 Acesso em: $01 \mathrm{dez}$. 2007. 
KNOWLES, D. P. Laboratory diagnostic tests for Retrovirus infections of small ruminants. Vet. Clin. North Am. Food Anim. Pract., v. 13, p. 1-11, 1997.

KNOWLES, D. P., EVERMANN, J. F., SHROPSHIRE, C., VANDERSCHALIE, J., BRADWAY, D., GEZON, HM., CHEEVERS, W.P. Evaluation of agar gel immunodiffusion serology using caprine and ovine lentiviral antigens for detection of antibody to caprine arthritis-encephalitis virus. J. Clin. Microbiol., v. 32, p. 243-245, 1994.

KNOWLES, D. P. Jr., CHEEVERS, W. P., McGUIRE, T. C., STEM, T., GORHAM, J. Severity of arthritis is predicted by antibody response to gp 135 in chronic infection with caprine arthritis-encephalitis virus. J. Virol., v. 64, p. 2396-2398, 1990.

LAAMANEN, I., JAKAVA-VILJANEN, M., SIHVONEN, L. Genetic characterization of maedi-visna virus (MVV) detected in Finland. Veterinary Microbiology, v. 122, p. 357-365, 2007.

LAIRMORE, M. D., POULSON, J. M., ADUCCI, T. A., DeMARTINI, J. C. Lentivirusinduced lymphoproliferative disease. Comparative pathogenicity of phenotypically distinct ovine lentivirus strains. Am. J. Pathol., v. 130, p. 80-90, 1988.

LARA, M. C. C. S. H. Artrite-encefalite dos Caprinos - Aspectos clínicos e epidemiológicos. 2002. 247 f. Tese (Doutorado) - Faculdade de Medicina Veterinária e Zootecnia, Universidade de São Paulo, 2002.

LARA, M. C. C. S. H.; BIRGEL JUNIOR, E. H. ; GREGORY, L. ; BIRGEL, E. H. Aspectos clínicos da artrite-encefalite dos caprinos. Arquivo Brasileiro de Medicina Veterinária e Zootecnia, Belo Horizonte - MG, v. 57, n. 6, p. 736-740, 2005.

LARA, M. C. C. S. H.; BIRGEL JUNIOR, E. H.; REISCHAK, D.; MOOJEN, V.; GREGORY, L.; OLIVEIRA, J. C. F.; BIRGEL, E. H. Identificação imuno-sorológica de anticorpos anti-vírus da artrite-encefalite dos caprinos: Comparação das técnicas de imunodifusão em gel de ágar, ensaio imunoenzimático e imunofluorescência indireta. Arquivos do Instituto Biológico, São Paulo - SP, v. 69, n. 4, p. 1-5, 2002.

LEITE, B. L. S.; MODOLO, J. R.; PADOVANI, C. R.; STACHISSINI, A. V. M.; CASTRO, R. S.; SIMÕES, L. B. Avaliação da taxa de ocorrência da Artrite-encefalite caprina a vírus pelas regionais do escritório de defesa agropecuária do Estado de São Paulo, Brasil, e seu mapeamamento por meio de sistema de informações geográficas. Arquivos do Instituto Biológico, v. 71, n. 1, p. 21-26, 2004.

LEGASTELOIS, I.; CORDIER, G., COZON, G.; CADORE, J. L.; GUIGEN, F., GREELAND, T.; MORNEX, J. F. Visna-maedi virus-induced expression of interleukin-8 gene is sheep alveolar cells following experimental in vitro and in vivo infection. Res. Virol., v.147, p.191-197, 1996a.

LEGASTELOIS, I.; LEROUX, C.; LEVREY, H.; MORNEX, J. F. Bases moléculaires des maladies liées aux lentivirus. Cahiers Agricultures, v. 5, p. 89-98, 1996b. 
LERONDELLE, C.; FLEURY, C.; VIALARD, J. Le gland mammaire: organe cible de l'infection par le virus de l'arthrite et de l'encéphalite caprine. Annales de Recherches Veterinaires, v. 20, n. 1, p. 57-63, 1989.

LERONDELLE, C.; GODET, M.; MORNEX, J. F. Instilation of primary culture of mammary epithelial cells by small ruminant lentiviruses. Veterinary Research, v. 30, n. 5, p. 467-74, 1999.

LERONDELLE, C.; GREENLAND, T.; JANE, M.; MORNEX, J. F. Infection of lactating goats by mammary instilation of cell-borne caprine arthritis-encephalitis virus.

Journal of Dairy Science, v. 78, n. 4, p. 850-855, 1995.

LEROUX, C.; VUILLERMOZ, S.; MORNEX, J.F.; GREENLAND, T. Genomic heterogeneity in the pol region of ovine lentivirus obtained from bronchoalveolar cells of infected sheep from France. J. Gen. Virol., v. 76, p. 1533-1537, 1995.

LIMA, P. P.; ROCHA, M. A.; STANCEK, D.; GOUVEIA, A. M. G.; OLIVEIRA, G. D. R. Vírus da artrite encefalite caprina: isolamento e caracterização de parte do gene gag. Arquivo Brasileiro de Medicina Veterinária e Zootecnia, v. 56, n. 2, p. 135-142, 2004.

LUJAN, L.; BEGARA, I.; COLLIE, D. D. S.; WATT, N. J. Ovine lentivirus (maedivisna virus) protein expression in sheep alveolar macrophages. Vet. Pathol., v. 31, p. 695-703, 1994.

MCELLIOTT, V.; VAPNIARSKY, N.; ROSS, A.; ROWE, J.; WOODS, L.; MURPHY, B. $\mathrm{G}$. The association of tissue tropism and promoter sequence variation in caprine arthritis-encephalitis virus infected goats. 2010. (não publicado)

McGUIRE, T. C.; NORTON, L. K.; O'ROUKE, K. L.; CHEEVERS; W. P. Antigenic variation of neutralization sensitive epitopes of caprine arthrittis-encephalits lentivirus during persistent infection. Vet. Med.Association. v. 62, p. 3488-3492, 1988.

MDURVWA, E. G.; OGUNBIYI, P. O.; GAKOU, H. S.; REDDY, P. G. Pathogenic mechanisms of caprine arthritis-encephalitis virus. Vet. Res. Commun. v. 18, p. 483490, 1994.

MELO, A. C. M.; FRANKE, C. R. Soroprevalência da infecção pelo vírus da artriteencefalite caprina (CAEV) no rebanho de caprinos leiteiros da região da Grande Fortaleza, Ceará, Brasil. Ciência Rural, v. 27, n. 1, p. 113-117, 1997.

MINISTÉRIO DA AGRICULTURA, PECUÁRIA E ABASTECIMENTO Programa Nacional de Sanidade dos Caprinos e Ovinos - PNSCO. Disponível em: http://www.agricultura.gov.br/ Acesso em: 08 dez. 2007.

MOOJEN, V.; CORREA SOARES, C.; RAVAZZOLLO, A. P.; DAL PIZZOL, M.; GOMES, M. Evidência de infeção pelo lentivirus (MAEDI/VISNA - Artrite-encefalite Caprina) em caprinos no Rio Grande do Sul, Brasil. (Comunicação científica). 
Arquivos da Faculdade de Medicina Veterinária da Universidade Federal do Rio Grande do Sul, v. 14, n. 14, p. 77-78, 1986.

MORNEX, J. F.; LENA, P.; LOIRE, R.; COZON, G.; GREENLAND, T.; GUIGUEN, F.; JACQUIER, M. F.; CORDIER, G. Lentivirus-induced interstitial lung disease:

pulmonary pathology in sheep naturally infected by the visna-maedi virus. Vet. Res., v. 25, p. $478-488,1994$.

MOTHA, M. X. J.; RALSTON, J. C. Evaluation of ELISA for detection of antibodies to CAEV in milk. Vet. Microbiol., v. 38, p. 359-367, 1994.

NAKAGAWA, M.; MOTOI, Y.; IIZUKA, M.; AZUMA, R. Histopathology of enzootic chronic polyartritis of goats in Japan. National Institute of Animal Health Quarterly. V. 11, p. 191-200, 1971.

NARAYAN, O.; CORK, L. C. (Ed.). Caprine arthritis-encephalitis virus. In: DINTER, Z.; MOREIN, B. Virus infections of ruminants. Amsterdam, Netherlands. Elsevier Science, 1990. p. 441-452.

NARAYAN, O.; CORK, L. C. Lentiviral diseases of sheep and goats: Chronic pneumonia, leukoencephalomyelitis and arthritis. Rev. Infect. Dis., v. 7, p. 89-97, 1985.

NARAYAN, O.; ZINK, C. M.; GORREL, M.; McENTEE, M.; SHARMA, D.; ADAMS, R. Lentiviurs induced arthritis in animals. J. Reumatologi. v. 32, p. 25-32, 1992.

NASH, J. W.; HANSON, L. A.; COATS, K. C. Bovine immunodeficiency virus in stud bull semen. American Journal of Veterinary Research, v. 56, p. 760-763, 1995.

NORMAN, S.; SMITH, M. C. Caprine arthritis-encephalitis: review of the neurologic form in 30 cases. J. Am. Vet. Med. Ass., v. 182, p. 1342-1345, 1983.

OIE/FAO. Animal Health Yearbook., 1997.

PEREIRA, M. F. Artrite-encefalite caprina a vírus (CAE) - estudo anatomopatologico e imunohistoquimico em cabras naturalmente infectadas. 1995. 64p. Escola de Medicina Veterinária UFMG, Belo Horizonte, 1995.

PERETZ, G.; ASSO, J.; DEVILLECHAISE, P. Le C.A.E.V.: revue des connaissances actuelles et consequences pratiques. Rev. Méd. Vét., v. 144, p. 93-98, 1993.

PERK, K. Ungulate lentiviruses: Pathogenesis and relationship to AIDS. Advances in Veterinary Science and Comparative Medicine, v. 32, p. 97-127, 1988.

PINHEIRO, R. R.; ALVES, F. S. F.; GIRÃO, E. S; MEDEIROS, L. P. A.; GIRÃO, R. N. Presença da artrite encefalite caprina a vírus (CAEV) em Teresina-Piauí. In: CONGRESSO BRASILEIRO DE MEDICINA VETERINÁRIA, 24. 1996, Goiânia. Anais... Goiânia: Sociedade Goiânia de Veterinária. 1996. p. 161. 
PINHEIRO, R. R.; GOUVEIA, A. M. G.; ALVES, F. S. F. Prevalência da infecção pelo vírus da Artrite Encefalite Caprina no Estado do Ceará, Brasil. Ciência Rural, v. 31, n. 3, p. 449-454, 2001.

PISONI G.; QUASSO A.; MORONI P. Phylogenetic analysis of small-ruminant lentivirus subtype B1 in mixed flocks: Evidence for natural transmission from goats to sheep. Virology, v. 339, p.147-152, 2005.

QUAYLE, A. J.; XU, C.; MAYER, K. H.; ANDERSON, D. J. T Iymphocytes and macrophages, but not motile spermatozoa, are a significant source of human immunodeficiency virus in semen. Journal of Infectious Diseases, v. 176, p. 960968, 1997.

QUERAT, G.; AUDOLY, G.; SONIGO, P.; VIGNE, R. Nucleotide sequence analysis of SA-OMVV, a visna-related ovine lentivirus: phylogenetic history of lentiviruses. Virology, v. 175, p. 434-47, 1990.

RAMALHO, E.; J. Artrite encefalite caprina - CAE: Prevalência de anticorpos séricos em caprinos no Estado da Bahia. 2000. 109 f. Tese (Doutorado em Clínica Veterinária) - Faculdade de Medicina Veterinária e Zootecnia, Universidade de São Paulo, São Paulo, 2000.

RAVAZOOLO, A. P.; REISCHAK, D.; PETERHANS, E.; ZANONI, R. Phylogenetic analysis of small ruminant lentiviruses from Southern Brazil. Virus Research, v. 79, p.117-123, 2001.

REDDY, P. G.; SAPP, W. J.; HENEINE, W. Detection of caprine atrhritisencephalites virus by polymerase chain reaction. J. Clin. Microbiol., v. 31, p. 30423043, 1993.

REISCHAK, D. Lentivírus de Pequenos Ruminantes: Imunofluorescência utilizando isolados brasileiros para diagnóstico sorológico de infecção em ovinos e caprinos. 2000. 132 p. Dissertação (Mestrado em Ciências Veterinárias) Faculdade de Veterinária, Universidade Federal do Rio Grande do Sul, Porto Alegre, 2000.

RIBEIRO, S. D. A. Caprinocultura: criação racional de caprinos. São Paulo. Nobel, 1997.318 p.

RIMSTAD, E., EAST, N., DeROCK, E., HIGGINS, J., PEDERSEN, N. C. Detection of antibodies to caprine arthritis-encephalitis virus using recombinant gag proteins.

Arch.Virol., v.134, p.345-356, 1994.

RIMSTAD, E., EAST, N.E., TORTEN, M., HIGGINS, J., DEROCK, E., PEDERSEN, N.C. Delayed seroconversion following naturally acquired caprine arthritisencephalitis virus infection in goats. Am. J.Vet. Res., v. 54, p. 1858-1862, 1993.

ROBINSON, W. F., ELLIS, T. M. The pathological features of an interstitial pneumonia of goat. J. Comp. Pathol., v. 94, p. 55-64, 1984. 
ROSADIO, R.; RIVERA, H. Mastitis intersticial linfoide asociada al virus de la artritisencefalitis caprina. Revista de Investigacion Pecuaria, v. 6, n. 2, p. 119-123, 1993.

ROWE, J. D.; EAST, N.E. Risk factors for transmission and methods for control of Caprine Arthritis-Encephalitis virus infection. Vet. Clin. North Am.: Food Anim. Pract., v. 13, p. 34-53, 1997.

ROWE, J. D.; EAST, N. E.; FRANTI, C. E.; THURMOND, M. C.; PEDERSEN, N. C.; THEILEN, G. H. Risk factors associated with the incidence of seroconversion to caprine arthritis-encephalitis virus in goats on California dairies. Am. J. Vet. Res., v. 53, p. 2396-2403, 1992.

ROWE, J. D.; EAST,N. E.; THURMOND, M. C.; FRANTI, C. E. Risk factors associated with Caprine Arthritis-Encephalitis virus infection in goats on California dairies. Am. J. Vet. Res., v. 52, p. 510-514, 1991.

RUFF, G.; LAZARY, S. Evidence for linkage between the caprine leucocyte antigen (CLA) system and susceptibility to CAE virus induced arthritis in goats.

Immunogenetics, v. 28, p. 303-309, 1988.

RUSSO, P.; VITU, C.; BOURGOGNE, A.; VIGNONI, M.; ABADIE, G.; DAVID, V.; PÉPIN, M. Caprine Arthritis-Encephalitis virus: detection of proviral DNA in lactoserum cells. Vet. Rec., v. 140, p. 483-484, 1997.

Saltarelli, M.; Querat, G.; Konings, D. A.; Vigne, R. and Clements, J. E. Nucleotide sequence and transcriptional analysis of molecular clones of CAEV which generate infectious virus. Virology, v. 179, p. 347-364, 1990.

SAMAN, E.; EYNDE; G.; LUJAN, L.; EXTRAMIANA, B.; HARKISS, G.; TOLARI, F.; GONZÀLEZ, L.; AMORENA, B.; WATT, N.; BADIOLA, J. A new sensitive serological assay for detection of lentivirus infections in small ruminants. Clin. Diagn. Lab.

Immunol. v. 6, n. 5, p. 734-740, 1999.

SANTA ROSA, J. Enfermidades em caprinos: diagnóstico, patogenia, terapêutica e controle. Sobral: Brasília, 1996. 220 p.

SARAIVA NETO, A. O.; CASTRO, R. S.; BIRGEL, E. H.; NASCIMENTO, S. A. Estudo soro-epidemiológico da artrite-encefalite caprina em Pernambuco. Pesquisa Veterinária Brasileira, v. 15, n. 4, p. 121-124, 1995.

SARGAN, D. R.; BENNET, I. D.; COUSENS, C.; ROY, D. J.; BLACKLAWS, B. A.; DALZIEL, R. G.; WATT, N., J., McCONNEL, I. Nucleotide sequence of EV1, a British isolate of maedi-visna virus. Journal of General Virology, v. 72, p. 1893-1903, 1991.

SCHROEDER, B. A.; OLIVER, R. E., CATHCART, A. The development and evaluation of an ELISA for detection of antibodies to Caprine Arthritis-encephalitis virus in goat serum. New Zeal. Vet. J., v. 33, p. 213-219, 1985. 
SERAKIDES, R.; NUNES, V. A.; PEREIRA, M. F. Estudo clínico, anatomopatológico e imuno-histoquímico de pulmões de cabras natualmente infectadas pelo vírus da artrite encefalite caprina (CAE). Arq. Brás. Med. Vet. Zoot. v. 48, n. 4, p. 415-424, 1996.

SHAH, C.; BONI, J.; HUDER, J. B.; VOGT, HR.; MUHLHERR J.; ZANONI R.; MISEREZ R., LUTZ H.; SCHUPBACH J. Phylogenetic analysis and reclassification of caprine and ovine lentiviruses based on 104 new isolates: evidence for regular sheep-to-goat transmission and worldwide propagation through livestock trade. Virology, v. 319, p.12-26, 2004.

SIMARD, C.; BRISCOE, M. An enzime-linked immunosorbent assay for detection of antibodies to maedi-visna virus in shep. II. Comparation to conventional agar gel immunodifusion test. Can. J. Vet. Res., v. 54, p. 451-456, 1990.

SIMS, L. D.; HALE, C. J.; McCORMICK, B. M. Progressive intersticial pneumonia in goats. Australian Veterinary Journal, v. 60, n. 12, p. 368-371, 1983.

SMITH, B. P. Tratado de medicina veterinária interna de grandes animais. São Paulo: Manole, 1993. p.1138-1139

SMITH, M. C.; CUTLIP, R. Effects on infection with caprine arthritis-encephalitis virus on milk production in goats. Journal American Veterinary Medical Association, v.193, n.1, p.63-7, 1988.

SMITH, M. C.; SHERMAN, D. M. Caprine arthritis encephalitis. In: Goat medicine. Philadelphia: Lea \& Febiger, 1994. p. 73-79.

STAVROU, D.; DEUTSCHLANDER, N.; DAHME, E. Granulomatous encephalomyelitis in goats. J. Comp. Pathol., v. 79, p. 393-396, 1969.

STÜNZI, H.; BUCHI, H. F.; LE ROY, H. L. Endemische Arthritis chronica bei Ziegen. Schweiz. Arch. Tierheilkd, v.106, p.778-788, 1964.

TAMURA, K.; DUDLEY, J.; NEI, M.; KUMAR, S. MEGA4: molecular evolutionary genetics analysis (MEGA) software version 4.0. Molecular Biology and Evolution, v. 24,n. 8, p. 1596-1599, 2007.

TRAVASSOS, C.; BENOIT, C.; VALAS, S.; SILVA, A.; PERRIN, G. Caprine arthritis encephalitis virus in semen of naturally infected bucks. Small Rumin. Res. v. 32, p. 101-106, 1999.

VALAS, S.; BENOIT, C.; GUIONAUD, C.; PERRIN, G.; MAMOUN, R. Z. North American and French Caprine Arthritis-Encephalitis Viruses Emerge from Ovine Maedi-Visna Viruses. Virology, v. 237, p. 307-318, 1997.

VITU, C.; RUSSO, P.,; FILIPPI, P.; VIGNE, R.; QUERAT, G., GIAUFFRET, A. Une technique ELISA pour la detection des anticorps anti-virus maedi-visna. Etude comparative avec l'immunodiffusion en gelose et la fixation du complement. Comp. Immunol. Microbiol. Infec. Dis., v. 5, p. 469-481, 1982. 
WOODWARD; J. C.; GASKIN, C.; POULOS, P. W.; MACKAY, R. J.; BURRIDGE, M. J. Caprine arthritis-encephalitis: clinicopathologic study. American Journal of Veterinary Research, v. 43, n. 12, p. 2085-2096, 1982.

ZANONI, R., KRIEG, A., PETERHANS, E. Detection of antibodies to caprine arthritisencephalitis virus by protein $G$ Enzyme-Linked Immunosorbent Assay and immunobloting. J. Clinical Microbiol. v. 27, p. 580-582, 1989.

ZANONI, R. Lentiviruses: A Brief Review. Etudes et Syntheses de I'TEMVT, n. 42, p. 1-8, 1993.

ZANONI, R. G.; VOGT, H. R.; POHL, B.; BÖTTCHER, J.; BOMMELI, W.;

PETERHANS, E. An ELISA based on whole virus for the detection of antibodies to small-ruminant lentiviruses. J. Vet. Med. B., v. 41, p. 662-669, 1994.

Zanoni, R. G., Phylogenetic analysis of small ruminant lentiviruses. J. Gen. Virol. v.79, pt.8, p. 1951-1961, 1998.

ZINK, M. C.; NARAYAN, O.; KENNEDY, P. G. E.; CLEMENTS, J. E. Pathogenesis of visna-maedi and caprine arthritis-encephalitis: new leads on the mechanism of restricted virus replication and persistent inflammation. Vet. Immun. Immunopathol., v. 15 , p. 167-180, 1987.

ZWAHLEN, M.; AESCHBACHER, M.; BALCER, Th.; STUCKI, M.; WYDERWALTHER, M.; WEISS und STECK, F.. Lentivirusinfektionen bei Ziegen mit Carpitis und interstitieller Mastitis. Schweiz. Arch. Tierheilk. v. 125, p. 281-299, 1983. 
ANEXO 1

\begin{tabular}{|c|c|c|c|c|c|c|c|c|c|c|c|}
\hline & AF108048 & AF108049 & AF108051 & 1AF108053.1M & AF108: & AF108059. & A, $/ 305050.1$ & A, 1305051 & $\mathrm{~A}_{\mathrm{N}}$ & $052.1 \mathrm{Br}$ & 05053.1 \\
\hline AF108048.1MG1-B1 & ID & 0,99 & 0,981 & 0,986 & 0,864 & 0,868 & 0,814 & 0,886 & & 0,841 & 0,886 \\
\hline AF108049.1MG1-B1 & & ID & 0,981 & 0,986 & 0,864 & 0,868 & 0,814 & 0,886 & & 0,841 & 0,886 \\
\hline AF108051.1MG1-B1 & & & ID & 0,995 & 0,864 & 0,868 & 0,805 & 0,877 & & 0,841 & 0,877 \\
\hline AF108053.1MG1-B1 & & & & ID & 0,868 & 0,873 & 0,809 & 0,882 & & 0,846 & 0,882 \\
\hline AF108056.1MG2-B1 & & & & & ID & 0,995 & 0,782 & 0,877 & & 0,891 & 0,877 \\
\hline AF108059.1MG2-B1 & & & & & & ID & 0,782 & 0,882 & & 0,895 & 0,882 \\
\hline A.J305050.1UFRGS & & & & & & & ID & 0,8 & & 0,787 & 0,8 \\
\hline AJ305051.1BrUFRGS4C18 & & & & & & & & ID & & 0,877 & \\
\hline AJ305052.1BrUFRGS5C47 & & & & & & & & & ID & & 0,877 \\
\hline A.J305053.1BrUFRGS2C767 & & & & & & & & & & & \\
\hline
\end{tabular}

Comparação entre o grupo seqüenciado obtido pelo GenBank Brasileiro 
ANEXO 2

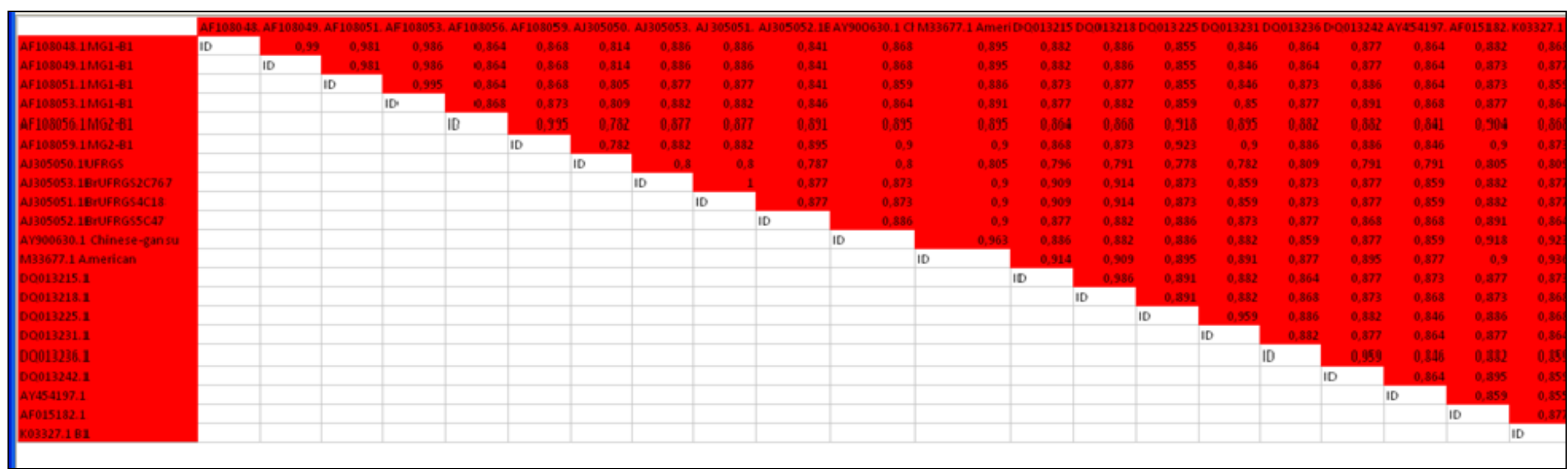

Comparação entre o grupo seqüenciado obtido pelo GenBank 
ANEXO 3

\begin{tabular}{|c|c|c|c|c|c|c|c|c|c|c|c|c|c|c|c|}
\hline \multirow{15}{*}{\begin{tabular}{|l} 
C8P Drica \\
C9C Drica \\
C10GM Drica \\
C16L \\
C17L \\
C29L Lisa esquerdo \\
C31L Astúria esquerdo \\
C103GM \\
C107C \\
C131L 5BC esquerdo \\
C132L 5BC direito \\
C137L 2S-7 \\
C144L Aviana \\
C148ST Aviana
\end{tabular}} & \multicolumn{5}{|c|}{ C8P Drica C9C Drica C10GM D C16L } & \multicolumn{5}{|c|}{ C17L C29L Lisa \&C31L Astúric103GM C107C } & \multicolumn{5}{|c|}{ C131L 5BC C132L 5BC (C137L 2S-7 C144L Aviana C148ST Avia } \\
\hline & ID & & & & 0,945 & 0,945 & 0,936 & 0,886 & 0,873 & 0,945 & 0,873 & 0,873 & 0,886 & 0,864 & 0,864 \\
\hline & & ID & & & 0.945 & 0.945 & 0.936 & 0,886 & 0,873 & 0,945 & 0,873 & 0,873 & 0,886 & 0,864 & 0,864 \\
\hline & & & ID & & 0,945 & 0,945 & 0,936 & 0,886 & 0,873 & 0,945 & 0,873 & 0,873 & 0,886 & 0,864 & 0,864 \\
\hline & & & & ID & & & 0,99 & 0,904 & 0,895 & 1 & 0,864 & 0,864 & 0,904 & 0,855 & 0,846 \\
\hline & & & & & & ID & 0.99 & 0.904 & 0,895 & 1 & 0,864 & 0,864 & 0,904 & 0.855 & 0,846 \\
\hline & & & & & & & ID & 0,895 & 0,886 & 0,99 & 0,855 & 0,855 & 0,895 & 0,846 & 0,837 \\
\hline & & & & & & & & 10 & 0,82 & 0.904 & 0,873 & 0,873 & 1 & 0,85 & 0,855 \\
\hline & & & & & & & & $\pi$ & & 0,895 & 0,886 & 0,886 & 0,882 & 0,85 & 0,841 \\
\hline & & & & & & & & & & ID & 0,864 & 0,864 & 0,904 & 0,855 & 0,846 \\
\hline & & & & & & & & & & & ID & & 0,873 & 0,864 & 0,864 \\
\hline & & & & & & & & & & & & ID & 0,873 & 0,864 & 0,864 \\
\hline & & & & & & & & & & & & & 10 & 0,85 & 0,855 \\
\hline & & & & & & & & & & & & & & ID & 0,977 \\
\hline & & & & & & & & & & & & & & & \\
\hline
\end{tabular}

Comparação interna entre os seqüenciados por Marjorie 
ANEXO 4

\begin{tabular}{|c|c|c|c|c|c|c|c|c|c|c|}
\hline & \multicolumn{10}{|c|}{ 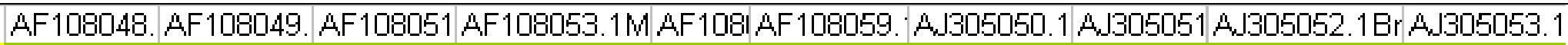 } \\
\hline C8P Drica & 0,868 & 0,868 & 0,859 & 0,864 & 0,895 & 0,9 & 0,8 & 0,873 & 0,886 & 0,873 \\
\hline C9C Drica & 0,868 & 0,868 & 0,859 & 0,864 & 0,895 & 0,9 & 0,8 & 0,873 & 0,886 & 0,873 \\
\hline C10GM Drica & 0,868 & 0,868 & 0,859 & 0,864 & 0,895 & 0,9 & 0,8 & 0,873 & 0,886 & 0,873 \\
\hline C16L & 0,868 & 0,868 & 0,868 & 0,873 & 0,909 & 0,914 & 0,809 & 0,882 & 0,877 & 0,882 \\
\hline C17L & 0,868 & 0,868 & 0,868 & 0,873 & 0,909 & 0,914 & 0,809 & 0,882 & 0,877 & 0,882 \\
\hline C29L Lisa esquerdo & 0,859 & 0,868 & 0,859 & 0,864 & 0,9 & 0,904 & 0,8 & 0,873 & 0,868 & 0,873 \\
\hline C31L Astúria esquerdo & 0,904 & 0,904 & 0,904 & 0,909 & 0,864 & 0,868 & 0,8 & 0,877 & 0,873 & 0,877 \\
\hline C103GM & 0,864 & 0,864 & 0,864 & 0,868 & 0,9 & 0,904 & 0,782 & 0,868 & 0,877 & 0,868 \\
\hline $\mathrm{C} 107 \mathrm{C}$ & 0,868 & 0,868 & 0,868 & 0,873 & 0,909 & 0,914 & 0,809 & 0,882 & 0,877 & 0,882 \\
\hline C131L 5BC esquerdo & 0,882 & 0,882 & 0,882 & 0,886 & 0,886 & 0,891 & 0,832 & 0,868 & 0,882 & 0,868 \\
\hline C132L 5BC direito & 0,882 & 0,882 & 0,882 & 0,886 & 0,886 & 0,891 & 0,832 & 0,868 & 0,882 & 0,868 \\
\hline C137L 2S-7 & 0,904 & 0,904 & 0,904 & 0,909 & 0,864 & 0,868 & 0,8 & 0,877 & 0,873 & 0,877 \\
\hline C144L Aviana & 0,864 & 0,864 & 0,864 & 0,868 & 0,85 & 0,846 & 0,823 & 0,855 & 0,841 & 0,855 \\
\hline C148ST Aviana & 0,855 & 0,855 & 0,855 & 0,859 & 0,841 & 0,837 & 0,814 & 0,864 & 0,846 & 0,864 \\
\hline
\end{tabular}

Comparação entre grupo seqüenciado Marjorie com grupo seqüenciado obtido do GenBank Brasileiro 
ANEXO 5

\begin{tabular}{|c|c|c|c|c|c|c|c|c|c|c|c|c|c|c|c|c|c|}
\hline & & & & & & & & & Av & 130: & & & & & 00132. & Q013231 & 1183 \\
\hline CSP Drica & 0,868 & 0,368 & 0,859 & 0,864 & 0,895 & 0,9 & 0,8 & 0,873 & 0,873 & 0,886 & 1 & 0,963 & 0,886 & 0,382 & 0,886 & 0,382 & 0,859 \\
\hline C9cDrica & 0,868 & 0,368 & 0,859 & 0,864 & 0,395 & 0,9 & 0,8 & 0,873 & 0,873 & 0,886 & 1 & 0,963 & 0,886 & 0,832 & 0,886 & 0,382 & 0,859 \\
\hline C10GM Drica & 0,868 & 0,368 & 0,859 & 0,864 & 0,895 & 0,9 & 0,8 & 0,873 & 0,873 & 0,886 & 1 & 0,963 & 0,886 & 0,882 & 0,886 & 0,382 & 0,859 \\
\hline C16L & 0,868 & 0,368 & 0,868 & 0,873 & 0,909 & 0,914 & 0,809 & 0,882 & 0,882 & 0,877 & 0,945 & 0,936 & 0,886 & 0,392 & 0,904 & 0,382 & 0,868 \\
\hline $\mathrm{C} 17 \mathrm{~L}$ & 0,868 & 0,368 & 0,868 & 0,873 & 0,909 & 0,914 & 0,809 & 0,882 & 0,882 & 0,877 & 0,945 & 0,936 & 0,886 & 0,832 & 0,904 & 0,382 & 0,868 \\
\hline C29L Lisa esquerdo & 0,859 & 0,368 & 0,859 & 0,864 & 0,9 & 0,904 & 0,8 & 0,873 & 0,873 & 0,868 & 0,936 & $0,9.27$ & 0,877 & 0,873 & 0,895 & 0,373 & 0,859 \\
\hline C103GM & 0,864 & 0,364 & 0,864 & 0,868 & 0,9 & 0,904 & 0,782 & 0,868 & 0,868 & 0,877 & 0,873 & 0,891 & 0,891 & 0,395 & 0,923 & 0,909 & 0,9 \\
\hline $\mathrm{C} 107 \mathrm{C}$ & 0,868 & 0,368 & 0,868 & 0,873 & 0,909 & 0,914 & 0,809 & 0,882 & 0,882 & 0,877 & 0,945 & 0,936 & 0,886 & 0,382 & 0,904 & 0,382 & 0,868 \\
\hline C131L 5BC esquerdo & 0,882 & 0,382 & 0,882 & 0,886 & 0,886 & 0,891 & 0,832 & 0,868 & 0,868 & 0,882 & 0,873 & $0,8.82$ & 0,859 & 0,855 & 0,882 & 0,364 & 0,914 \\
\hline C132L 5BC direito & 0,382 & 0,382 & 0,882 & 0,886 & 0,886 & 0,891 & 0,832 & 0,868 & 0,868 & 0,882 & 0,873 & 0,882 & 0,859 & 0,855 & 0,882 & 0,364 & 0,914 \\
\hline C144L Aviana & 0,864 & 0,364 & 0,864 & 0,868 & 0,85 & 0,846 & 0,823 & 0,855 & 0,855 & 0,841 & 0,864 & 0,873 & 0,855 & 0,355 & 0,355 & 0,368 & 0,85 \\
\hline C143ST Aviana & 0,855 & 0,355 & 0,855 & 0,859 & 0,841 & 0,837 & 0,814 & 0,864 & 0,864 & 0,846 & $0,86-4$ & 0,873 & 0,855 & 0,859 & 0,846 & 0,359 & 0,855 \\
\hline
\end{tabular}

Comparação entre grupo seqüenciado Marjorie com grupo seqüenciado fora do Brasil, obtido do GenBank 